\title{
Türk Çay Sektöründe Yasal Gelişim ve 1984 Serbestleştirmesi
}

Ali Rıza Saklı1

Türk Çay Sektöründe Yasal Gelişim ve 1984 Serbestleştirmesi

Öz

Tarihi süreçte, belli alanlardaki yasa değişimlerinin ele alınması, değişimi gerektiren durumların ve hayata geçirilen uygulamaların izlenmesi bakımından yarar sağlamaktadır. Türk çaycılığının yasal gelişiminin ele alınması bir ölçüde ihmal edilmiş sayılabilir. Bu çalışmada, önde gelen çay yetiştirici ülkelerden Hindistan, Sri Lanka ve Kenya çay yasaları kabaca incelenerek; üç ülkenin de kapsamlı yasal düzenlemelere sahip oldukları görülmüştür. Türkiye'de eski tarihli çay yasaları daha kapsamlı olduğu halde, 1984 tarihli yasanın serbestleştirme (deregulation) kaygısıyla hazırlandığı anlaşılmaktadır. 1984 serbestleştirmesi, çay sektöründe sorunların çözümünü sağlamadığı gibi, birçok soruna kaynaklık etmiş, özel sektörün kayda değer bir başarı göstermesini de sağlamamıştır. Bu çalışmada, serbestleşme döneminde yaşanan sorunlar belirlenmeye çaışıımıştır. Ayrıca bu sorunların çözümü için yeni bir çay yasası çıkarılması; çay kurulu ve çay borsası kurulması, çay imalatının standartlara bağlanması, yeni bir yaş çay toplama düzeni kurulması gibi öneriler getirilmiştir.

Anahtar Kelimeler: Çay, Rize, Çay kanunları, Çay sektöründe serbestleştirme
Legal History in Turkish Tea Sector and 1984 Deregulation Abstract

In the historical process, addressing changes in law in certain areas, benefit the monitoring both of the situations that require the change and implemented applications. The legal development of Turkish tea sector may be considered to be neglected or disregarded so far. In this study, the tea laws of India, Sri Lanka and Kenya, as leading tea growing countries, were roughly reviewed and seen that the three countries had extensive legal regulations. Although Turkey's oldest tea laws are more comprehensive, the law of 1984 is not the same, as prepared for liberalization and deregulation purposes. The deregulation of 1984 has been a source of many problems in the tea industry, and has not led to a remarkable success of the private sector. In this study, the problems experienced during the deregulation period were tried to be determined. In addition, the adoption of a new tea law to solve these problems and establishing tea board and tea stock exchange, setting up tea production standards, founding a new fresh tea collection system was proposed.

Keywords: Tea, Rize, Tea acts, Deregulation on tea sector

\section{Giriş}

Türkiye'de çaycılıkla ilgili yasama faaliyetleri, Cumhuriyet'le yaşıt sayılır. Çayı konu alan ilk yasa, 1923'te teklif olarak verilmiş ve 1924'te yasalaşmıştır. Bu derinliğe rağmen, çay yasalarının tarihi gelişimi, çay konusunu ele alan farklı çalışmalardaki kısa değinmeler istisna edilirse, araştırmalara konu edilerek incelenmemiştir.

Önemli tartışmalara konu olan 1980'li yılların başındaki Yeni Kamu Yönetimi (bazı yazarlara göre Kamu İşletmeciliği) yaklaşımı, çay sektöründe önemli bir uygulama ile kendini göstermiştir. 1984 'te çıkarılan bir yasa ile çay sektöründe serbestleştirme (deregulation) sağlanmıştır. Çay sektöründe özel kesimin çay işleme ve pazarlamasına izin verilmiş, bir maddesi yürürlük, bir maddesi yürütme ve bir maddesi de yürürlükten kaldırılan mevzuat olan beş maddelik bir yasa ile yetinilmiştir. Türkiye'deki en önemli serbestleştirme faaliyeti bu olduğu halde, kamu yönetimi araştırmacıları, serbestleştirme üzerine genel söylemlerle yetinmiş, çay sektöründeki serbestleştirme incelenmemiştir.

Önde gelen çay yetiştiricisi ülkeler olan; Hindistan, Sri Lanka ve Kenya'daki yasal durum ve sektörel yapılanma da, bir iki çalışma hariç, çok fazla incelenmemiştir. Bu ülkelerdeki sektörel yapılanmalar incelemeye konu edilmiş (Saklı, 2004, Saklı, 2008) olmakla birlikte, yasal durum ve gelişim ele alınamamıştır.

${ }^{1}$ Doç.Dr., Recep Tayyip Erdoğan Üniversitesi, iiBF, Siyaset Bilimi ve Kamu Yönetimi Bölümü. aliriza.sakli@erdogan.edu.tr, yazar ORCID bilgisi: https://orcid.org/0000-0002-7681-9253 
Bu çalışmada, yabancı ülkelerdeki yasaların kapsamına dikkat çekildikten sonra, Türk çayının yasal gelişimi; yasaların getirdiği yenilikler ve bunların uygulamaya olan yansımalarına da yer verilerek incelenmeye çalışıımıştır. 1984'te uygulanan Türkiye'deki en önemli serbestleştirme faaliyeti, uygulama sonuçları ile birlikte değerlendirilmeye çalışımıştır.

Çay yasalarının kronolojisini vermek yerine, her bir çay yasası çıkarılmadan önce ortaya çıkan ihtiyaç, TBMM'deki görüşme ve tartışmalar ile çıkarılan yasanın uygulamaları dâhil olmak üzere, çok yönlü bir inceleme yapılmaya çalışılmıştır. Bir ölçüde, Türkiye' de çay tarımındaki gelişmeler üzerine, yasal mevzuattaki değişmelerin etkilerinin incelendiği söylenebilir.

\section{2. Çay Yetiştiren Ülkelerde Çay Yasaları}

Çay yasası denildiğinde, ilk olarak 1773 yılında İngiltere tarafından çıkarılan Çay yasası akla gelir. İngiliz Doğu Hindistan Şirketi'ne çay piyasasında tekel hakkı veren yasa, o dönemde bir İngiliz kolonisi olan Amerika'da çaya da vergi koymaktaydı. İngiltere'nin Amerika'da uygulamaya koyduğu bir dizi başka vergileri izleyen bu işlem, 16 Aralık 1773'te Boston'da bir eylemin başlamasına yol açtı. Boston limanı'nda 45 ton çayın denize döküldüğü bu toplu eylem, Boston Çay Partisi olarak tarihe geçti ve Amerika'nın İngiliz kolonyalist idaresine karşı başkaldırııını başlattı (Connely, 2011: 24).

Bilindiği gibi, çay ticareti üzerinde uzun süre kontrol kuran, 1835-1998 yılları arasında çay fiyatlarının Londra Çay Borsası'nda belirlendiği bir ülke olan İngiltere, çay üreticisi bir ülke değildi (Saklı, 2008). Hindistan ve Sri Lanka'nın bağımsızlığa kavuşmaları ile birlikte, İngiltere'nin çay üzerindeki kontrolü yavaş yavaş ortadan kalkmaya başlamış ve çay üreticisi olan bu ülkeler kendi ürünleri üzerinde kontrol kurmaya başlamışlardır. Söz konusu değişim, bu ülkelerin çıkardıkları çay yasaları (tea acts) ile de izlenebilmektedir.

Hindistan'da ilk çay tarımı İngiliz sömürge idaresi altında $1828^{\prime}$ de Assam'da başladı. Assam Şirketi, 1834'te kuruldu (Sarma, 2013). Hindistan'ın ilk çay borsası olan Kalküta Borsası 1861'de kuruldu. Bağımsızlık kazanıldıktan sonra, 1953 yılında çıkarılan Hindistan Çay Yasası, 51 madde ve birçok fıkradan oluşan geniş bir kanundur. Yasa, Hindistan Çay Kurulu'nu (Tea Board) üst kuruluş olarak yetkilendirmiş ve sektörün yönetimini ona vermiştir (The Tea Act, 1953).

Sri Lanka'da İngiliz kolonisi olarak çay üretimi başlamış ve 1839'da Hindistan'da olduğu gibi Sri Lanka'daki çaylık alanlar da İngiliz Doğu Hindistan Şirketi tarafından satın alınmıştır. 1870'lere kadar kahve üreticisi de olan Sri Lanka, bu dönemde kahvede ortaya çıkan kahve pas hastalığı sebebiyle tümüyle çay üretimine geçmiştir (Teasrilanka, 2017). Önce genel bir ürün borsası olan Kolombo Çay Borsası, Kolombo Çay Tüccarları Birliği yönetimi altında, 1894'te sadece çay ticaretine yönelmiştir (Tea Convention, 2017).

Ülke 1948'de İngiltere'den bağımsızlığını kazandıktan sonra, 1957 yılında Sri Lanka Çay Kontrol Yasası (Tea Control Act) çıkarılmış ve çaylık alanlarla birlikte çay çiftçilerini ve çay fabrikalarını da kayıt ve kontrol altına almayı amaçlamıştır. Çay sektöründe geniş bir düzenlemeye giden Yasa, 63 maddeden meydana gelmekteydi. Çay sektörü ile ilgili bir Çay Danışma Kurulu kurmakla yetinen Kanun'dan sonra, 1975'te Sri Lanka Çay Kurulu Yasası çıkarılmış ve sektörün yönetimini bu üst kurula vermiştir. (Sri Lanka Tea Board Law, 1975).

Çay üretimi faaliyetlerine daha geç bir dönemde başlayan Kenya, ilk çay yasasını 1961 yılında çıkarmıştır. 26 maddeden oluşan Kenya Çay Yasası (1961), Kenya Çay Kurulu’nu kurup yetkilendirmekte ve çay sektörünün yönetimini bu kurula vermektedir.

Türkiye'de çayla ilgili ilk yasa 1924 yılında çıkarılan; Rize Vilâyetiyle Borçka Kazasında Fındık, Portakal, Limon, Mandalina ve Çay Yetiştirilmesi Hakkında Kanun'dur. Adından da anlaşıldığı 
üzere, Yasa sadece çayı konu edinmemiş, Rize vilayeti ve Artvin'in Borçka kazasında yetişmesi mümkün olan beş farklı üründen biri olarak çaya yer vermiştir.

İkinci yasa, 1940 yılında yasalaşan 3788 Sayılı Çay Kanunu'dur. Bu defa doğrudan doğruya ve sadece çay konusunu ele alan bir kanun metni söz konusudur. 1938'de Zihni Derin öncülüğünde Rize'de başlatılan çaycılık çalışmalarının yasal altyapısı bu şekilde sağlanmış olmaktaydı.

\section{3. Çayda ve Sair Alanlarda Yasal Gelişim Literatürü}

Çayın yasal gelişimi ile ilgili ülkemizde yapılan çalışmaları araştırdığımızda, salt bu konuyu ele alan bir bilimsel çalışma olmadığı görülmektedir. Bununla birlikte, hemen her çay incelemesinde çay yasalarına değinildiği, bazı çalışmalarda kısa bir yasal gelişime yer verildiği, ama genellikle konunun üzerine yeterince eğilinmediği anlaşılmaktadır.

Çay İşletmeleri Genel Müdürlüğü (Çaykur) yayınlarına baktığımızda; Faaliyet Raporu ve İstatistik Bülteni şeklinde iki yayının devamlılık gösterdiği tespit edilebilmektedir. Her iki yayının ortak özelliği yasal gelişimi Çaykur ile başlatmaları ve kurumsal bir yasal gelişime yer vermiş olmalarıdır.

2017 Çaykur İstatistik Bülteni (2017: 5) incelendiğinde, "Hukuki Yapı" başlığı altında tek sayfalık bir yasal gelişime yer verildiği anlaşılmaktadır. Çaykur'un kuruluş yasası olan 06.12.1971 tarih ve 1947 sayılı Kanun'la başlayan, 18.10.1983 tarih ve 112 sayılı Çay İşletmeleri Genel Müdürlüğü Kuruluşu Hakkında KHK ile devam eden metinde; kurumun İktisadi Devlet Teşekkülü (IDT) olarak kurulduğu ve 1983'te Kamu İktisadi Kuruluşuna (KiK) dönüştürüldüğü bilgisine yer verilmektedir. 233 sayılı Kamu İktisadi Teşebbüsleri Hakkında KHK ile 112 sayılı KHK'nın yürürlükten kaldırıldığı ve kurumun 233 sayılı KHK'ya tabi hale getirildiği bilgisine yer verilmektedir. 04.12.1984 tarih ve 3092 sayılı Çay Kanunu ile çayda devlet tekelinin kaldırılarak, çay işletmeciliğinin serbest bırakıldığı belirtilmektedir. 24.11.1994 tarih ve 4046 sayılı Kanunun 35/a maddesi ile kurumun İktisadi Devlet Teşekkülü (IDT) statüsüne alındığı ifade edilmektedir.

Çaykur'da çalışan memurların 657 sayılı Kanun'a sözleşmeli personelin ise 399 sayılı KHK'ya, iş̧̧ilerin ise 4857 sayılı İş Kanununa tabi olduğu bilgisi verilmektedir. 2013 yılında yapılan Ana Statü değişikliği anlatılmakta, 3346 sayılı Kanun gereğince kurumun TBMM tarafından ve 6085 sayılı Sayıştay Kanunu gereğince de Sayıştay tarafından denetlendiği belirtilmektedir. Son olarak, kurumun, 19 Ağustos 2016 tarihinde kabul edilen 6741 sayılı kanun gereğince Türkiye Varlık Fonu Anonim Şirketine devredildiği ifade edilmektedir. (Çaykur İstatistik Bülteni, 2017)

2017 yılı Çaykur Faaliyet Raporu'nda (2017: 2,3) bir buçuk sayfalık bir Hukuki Durum bilgisine yer verilmektedir. Kuruluş tarihi ve IDT olarak kuruluşu İstatistik Bülteni'ndeki gibi verildikten sonra, 20.05.1983 tarihinde Kamu Iktisadi Teşebbüsleri'nin yeniden düzenlenmesi için 60 Sayılı KHK'nın çıkarıldığı bildirilmektedir. Sonra bu KHK'da değişiklik yapılarak; Çaykur'un, Çay İ̧̧letmeleri Genel Müdürlüğü adı altında bir KiK haline getirildiği; hukuki bünyesi, örgüt yapısı ve organları ile ilgili konuların yeniden düzenlendiği belirtilmektedir.

Faaliyet Raporu'nun Hukuki Durum başlıklı bilgilerinin devamında; 28.10.1984 tarihinde Çaykur' un yeniden teşkilatlandırıldığı ve bunun da ana statüsünün belirlenmesi suretiyle yapıldığı belirtilmektedir. 04.12.1984 tarih ve 3092 Sayılı Kanun ile "çay ürününün tarımı, üretimi, işletmesi ve satışının serbest bırakıldığı" ifade edilmektedir. 233 Sayılı K.H.K. çerçevesinde faaliyetlerini sürdüren kurumun faaliyetlerini özel bir şekilde yürüttüğü ve tüzel kişiliğe haiz olduğu bildirilmektedir. Bir KiT olan Çaykur'un özerk bir kurum olduğu açık olduğu halde, metinde "özel" ifadesinin kullanılması ve özerklikten bahsedilmemesi manidardır. 
Kurumun kuruluş sermayesine ilişkin bilgi verildikten sonra, Ana Statüsü’ne değinilmiş; tüm unsurları ile ana statünün detayları sıralanmıştır. 11.04.2013 tarih ve 28615 sayılı Resmi Gazetede yayımlanan Çaykur Ana Statüsü ile yapılan yenilik, daha önce sadece Camellia Sinensis türündeki çay türleri konusunda yetkili kılınan kurumun, bu defa "her türlü çay ürünü" konusunda yetkilendirildiği görülmektedir. Bu çerçevede kurumun, "bitkisel çaylar, soğuk çay, kafein, ekstrat ile diğer ilişkili ve yan sektörlere ait ürünlerin üretimini ve pazarlamasını yapmak" yetkisine kavuşturulduğu ifade edilmektedir (Çaykur Faaliyet Raporu, 2017).

Daha önce çay sektöründeki yasal gelişimi ana konu olarak ele alan bir çalışma mevcut değildir. Farklı açılardan çayı ele alan bazı çalışmalarda çay yasalarına değinilmiş, bir çalışmada ise kurumsal ve yasal gelişim sürecine bir başlık altında yer verilmiştir. Özçelik ve arkadaşları (2013) tarafından yapılan çalışmada, yasal gelişim 1971'le başlatılmış, 1924 ve 1940 yıllarında çıkarılan yasalara değinilmemiştir. 1971 tarih ve 1497 sayılı Çay Kurumu Kanunu'na değinilmesinin nedeni, kurumsal gelişim olarak görünmektedir. 1984'te ise özel sektöre çay üretim ve ticaret izni verilmesine değinilmekle yetinilmiştir. Anlaşıldığı üzere asıl yapılmak istenen kurumsal gelişimin izlenmesidir; yasal gelişim ayrıntılı biçimde ele alınmamıştır.

Kemaloğlu (2015) tarafından yapılan çalışmada "Türkiye'de Afet Yönetiminin Tarihi ve Yasal Gelişimi" ele alınmıştır. Araştırmada Türkiye'deki afet potansiyeli ele alınmış, afet yönetimi yapılanması ve kurumsal gelişim incelenmiş, afet yönetimi kavramsal olarak ele alınmıştır. Çalışmanın son bölümünde, "afet yönetimi, seferberlik, koruyucu güvenlik, yangın ile ilgili mevzuat" dört alt başlık altında aynı tabloda verilmiştir. Sadece mevzuatın sayısı, adı ve Resmi Gazetede yayın tarih ve sayısına yer verilen bir listeleme ile yetinilmiştir. Her bir mevzuatın ilgili alanda getirdiği yenilikler ve değişiklikler ele alınmamış ve tartışılmamıştır.

Kejanlı ve arkadaşları (2007) Türkiye' de koruma yasalarının tarihi gelişimimi incelemişlerdir. Tarihsel çevre koruması ele alınan çalışmada önce "koruma" kavramı ve anlayışının gelişimi ele alınmış, 1930'dan itibaren yasal gelişimin incelenmesine başlanmıştır. 1930-50 dönemi ve 195080 dönemindeki yasal gelişim ayrı başlıklar halinde ele alınmıştır. 1980-2004 dönemi ve 2004 sonrası dönem de ayrı ayrı ele alınmıştır. Dönemler itibariyle yasal gelişimin analize tabi tutulduğu çalışmada, 2004 yılında kurulan koruma düzeni içinde akademisyenlere görev verilmiş olması ve oluşan yeni düzen anlatılmıştır.

Yasal gelişim konusu sadece çay sektöründe değil, diğer sektör ve alanlarda da yeterince ele alınmış değildir. Yasal değişimin ortaya çıkardığı yeni durum ve bunun etkilerinin incelemelere konu edilmesi, yasa yapıcıların daha bilinçli hareket etmelerini sağlama yönünde katkı sunabileceği ve bu sebeple bu alandaki çalışmaların önemli olduğu değerlendirilmektedir.

\section{Türkiye'de Çay Yasalarının Gelişimi}

1917 Ekim Devrimi'nden sonra kurulan Sovyetler Birliği'nin sınır kapılarından serbest geçişleri durdurması sebebiyle Sarp sınır kapısının kapatılması, daha önce Rusya ve Romanya gibi ülkelere çalışmaya giden Rize halkını zor durumda bırakmıştır. Rize'de geçim zorlaşmış, ülke içinde iş arayışları yeterli olmamış ve eşkıyalık gibi bir kısım asayiş olayları artmıştır. Bu durumu görüşmek üzere 1920'de Bakanlıklar arası bir toplantı düzenleyen birinci TBMM Hükümeti konuya el atmıştır. Toplantıya İktisat Bakanlığı adına katılan Ziraat Genel Müdürü Zihni Derin, Rize'nin geçim şartlarının iyileştirilmesi konusunu araştırmakla görevlendirilmiştir (Zihnioğlu, 1998).

Rusya'nın 1917'de işgal ettiği Kars, Ardahan, Artvin, Rize ve Batum'u terk etmesiyle, bu yerlerde tarımsal incelemeler yapması için bir heyet görevlendirilmiştir. 1918 yılında söz konusu 
illere giden heyette yer alan Halkalı Yüksek Ziraat Mektebi Müderrisi (Profesör) Ali Rıza Erten (1925), "Şimali Şarki Anadolu ve Kafkasya'da Tetkikatı Ziraiye" adlı bir Rapor kaleme almıştır. Ali Rıza Erten'in İktisat Bakanlığı'na sunduğu raporu bilen Zihni Derin, raporda yer alan; 'Batum'da çayın yetişmekte olduğu ve aynı iklime sahip Rize'de de çay yetiştirilebileceği' bilgisine sahiptir. Rusya'dan Batum hakkında dergiler de getirten Derin, burada portakal, mandalina, limon ve çay yetiştirilmesi üzerinde durmuştur (Hatipoğlu, 1939).

Zihni Derin, Ziraat Genel Müdürü sıfatıyla Ankara'dan verdiği talimatla, Rize'de ilk narenciye, bambu ve çay fidanlığını kurdurmuştur. 1921'de kurulan fidanlığa, Batum'dan getirttiği; portakal, mandalina, limon, çay ve bambu fidanları dikilmiştir. 1924 yılında Ziraat Genel Müfettişi olarak atanınca Rize'ye gitmiş, fidanlık için Garal Dağı denilen ve bugünkü Ziraat Çay Bahçesi'nin bulunduğu tepede, gerekli istimlak işlerini tamamlamıştır. Rize'den Batum'a geçen Derin, oradan getirdiği fidan ve tohumları yeniden kurduğu çay ve narenciye fidanlığına diktirmiştir. Bu bilgileri, çay uzmanı Mr. Moore'un sorularına verdiği cevaplardan, (Derin, ?) çıkarıyoruz. Batum'dan döndükten sonra, kurduğu fidanlığı beraberinde getirdiği Rus bahçıvana bırakarak Ankara'ya dönmüş ve 407 sayılı Kanun'u çıkarmak için çalışmıştır (Zihnioğlu, 1998).

\subsection{Tarih ve 407 Sayılı Kanun}

6 Ekim 1923'te, Rize Milletvekili Esad Bey (Esad Özoğuz) tarafından, “Lazistan (1924'te Rize) Livasında fındık, portakal, limon, mandalina, çay, dut yetiştirilmesi hakkında" bir kanun teklifi verilmiştir (TBMM Zabıt Ceridesi, 28.01.1924). Kanun teklifi, önce iktisat Komisyonu ve Bütçe Komisyonu'nda görüşülmüş, değişiklik önerileri ile kabul edilerek TBMM Genel Kurulu'na gelmiştir.

Esad Bey'in kanun teklifi gerekçesinde; Rize'nin nüfusuna göre arazisinin az olduğu; çoğu yerleri dağlık ve çalılık olduğundan arazinin üçte yahut dörtte birinin kullanılabilir durumda bulunduğu ve seçeneklerinin diğer yerlere göre daha sınırlı olduğu anlatılmaktadır. Rize'de fındık, portakal, mandalina, limon, çay, dut yetişebildiği, bu sebeple mevcut kızılağaçların kesilip koparılması ve yerine bu fidanların dikilmesi gerektiği, bunun için de bir kısım özel izinlerin ve ödeme hükümlerinin gerekli olduğu belirtilmektedir (TBMM Zabıt Ceridesi, 1924: 423).

Esad Bey'in bahsettiği özel izinler, Rize'de eğimli arazilerde başka bir ürün yetişmediğinden halkın çok cüzi bir gelir için ticaretini yapmaya çalıştığı kızılağaçların kesilmesi ile ilgili olmalıdır. Çünkü bunların kesilmesi ve köklerinin sökülmesi için orman sayılmamaları gerekmekteydi. Ödeme olarak bahsedilen ise; tekliften çıkarılacak olan, oluşturulacak bahçelerin dekarı başına 10 lira ödenmesi hükmüdür.

Teklifle ilgili Dilekçe Komisyonu'nun kısa tutanağında; arazisine göre nüfus yoğunluğunun fazla olması ve arazisinin dağlık ve ziraatın iptidai olması gerekçeleriyle "halkın önemli bir kısmı evvelce Rusya'ya, Romanya'ya gider; fırıncılık, hızarcılık, müteahhitlik, balıkçılık, amelelik ve ticaretle iştigal ederek müreffeh bir hayat temin ederlerdi" denilmektedir. I.Dünya Savaşı'ndan sonra bu imkânın ortadan kalktığı, halkın bir kısmının İzmit, Bolu ve Düzce'ye göç etmek mecburiyetinde kaldığı, "halen zaruret pek feci bir surette devam etmekte ve sonucunda eşkıyalık, kan davaları ve sefalet artmaktadır" bilgisi verilmektedir (TBMM Zabıt Ceridesi, 1924: 423).

Esad Bey'in Kanun Teklifi'nin 1.Maddesi, günümüz Türkçesi ile söyle ifade edilebilir: "Lazistan Sancağı'nın sahil kesimindeki kızılağaçları, çalıları kesip koparmak suretiyle, yerlerine fen memurlarının raporuna mahallerinin kabiliyetine göre Hükümetçe ücretsiz verilecek fındık, por- 
takal, mandalina, limon, çay, dut fidanı dikilmesine sahipleri mecburdur." Burada dikkat edilmesi gereken konular; fidanların halka ücretsiz temin edilmesi ve halkın yeni bitkileri dikmeye mecbur edilmesidir.

İzmir Milletvekili Mahmut Celal'in (daha sonra III. Cumhurbaşkanı Celal Bayar) Başkanı olduğu İktisat Komisyonu, birinci maddedeki "dut fidanı dikilmesi” mecburiyetinin kaldırılmasına karar vermiştir. İkinci madde Komisyonca değiştirilerek; halka çay ziraatını ve sanatı öğretecek ve ücretsiz fidan temin edecek bir fidanlık tesis edilmesi ve bir uzman görevlendirilmesi hükmü getirilmiştir. Teklifin beşinci maddesinde, vergi muafiyeti teşviki beş yıldan on yıla çıkarılmış ve bir defaya mahsus dönüm (dekar) başına 10 lira nakit para mükâfatı konulmuştur.

Bütçe Komisyonu, halka mecburiyet getiren birinci maddeyi kabul etmiş, fidanlık kurularak uzman görevlendirilmesine ilişkin ikinci maddeyi; zaten fidanlık kurulmuş olduğu gerekçesiyle çıkarmıştır. Halka bedelsiz fidan verilmesini uygun görmüş ama en önemli madde olan dönüm başı 10 lira mükâfat verilmesini kabul etmemiştir. Buna karşılık, bahçe tesis edenden 10 yıl süreyle vergi ve öşür alınmaması teklifini uygun bulmuştur.

İki Komisyonun farklı yaklaşımlar sergilemesi milletvekilleri tarafından yapılan görüşmelerde ele alınmış; bazı vekiller mecburiyet konulmasını uygun bulmazken, bazıları da dönüm başı 10 lira ödül verilmesini uygun görmemişler, bir kısmı da Kanun'un tüm ülkeyi kapsamasını talep etmişlerdir. Bunun üzerine Iktisat Komisyonu Başkanı M.Celal Bayar söz alarak; Rize'nin iklimi, sosyal durumu ve özellikleri sebebiyle kanunun Rize'ye hasredildiğini anlatmıştır. Kanun üzerine çeşitli tartışmalardan sonra iktisat Komisyonu teklifi tekrar görüşmek üzere geri almış ve 04.02.1924 tarihinde görüşülmek üzere tekrar Meclis Genel Kuruluna göndermiştir.

İktisat Komisyonu'nca kaleme alınan gerekçede yer verilen şu ifade, Rize'nin bütün kurumlarıyla kanunun arkasında olduğunu göstermektedir: "Kanun teklifinin, yalnız bir milletvekilinin düşünce ürünü olduğu zannedilmemelidir. Rize Vilayeti Ticaret ve Ziraat Odaları memurları, il Genel Meclisi ve il İdare Kurulu mensupları ve bu halkın içinden doğmuş dertlerini en yakından bilen temsilcileri olan Milletvekilleri tarafından ittifakla ve hararetle kabul ve müdafaa edilen ve çok kuvvetli iktisadi ve sosyal gerekçelere dayanan bir tekliftir." (TBMM Zabıt Ceridesi, 1924: 568).

Tam adı; Rize Vilâyetiyle Borçka Kazasında Fındık, Portakal, Limon, Mandalina ve Çay Yetiştirilmesi Hakkında Kanun" olan 407 sayılı yasal düzenleme, başlangıçta "Lazistan" sonra "Rize Vilayeti” ile sınırlı bir metindi. İkinci defa İktisat Komisyonu’na gönderilip geri geldiğinde "Borçka Kazası"nın kanuna dâhil edilmiş olduğu görülmüştür.

Kanunun Rize dışındaki vilâyetlere de uygulanması taleplerine şiddetle karşı çıkan İktisat Komisyonu, Borçka'nın dâhil edilmesini bizzat teklif etmiştir. Bu yaklaşım, ilk olarak Borçka'nın Batum'a yakın olması sebebiyle, ülkenin diğer yerlerine karşı öne sürülen 'iklimin uygunluğunun belirlenmesi' gerekliliğinin bulunmaması, ikincisi Batum ile aynı toprak yapısına sahip bulunması şeklinde ortaya konulmuştur.

Borçka'nın yasaya dâhil edilmesinde daha önemli bir gerekçe mevcuttur. Bu da geçim sıkıntısının Rize'de olduğu gibi Borçka'da da devam ediyor olmasıdır. Hatta verilen bazı göç rakamları, durumun Rize'den de kötü olduğunu göstermektedir: “Mesela Kanapya deresi köylüsü 300 hane iken 27 hane kalmıştır. İçkale köylüsü 500 hane iken 60 hane kalmıştır. Devigel vadisi köylüsü 450 hane iken 50 hane kalmıştır" (TBMM Zabıt Ceridesi, 1924: 570).

Kanun'un neden "Rize Vilayeti ve Borçka Kazası”nı kapsayacak şekilde çıktığını açıklığa kavuşturduktan sonra hükümlerine geçebiliriz. Kanun'un birinci maddesi; “Rize vilâyetiyle Artvin 
vilâyetinin Borçka kazası dâhilinde mevcut arazideki çalılık ve kızılağaçların ziraat fen memurunun vereceği rapora nazaran kesilip koparılmasıyla yerlerine arazinin yetiştirme kabiliyetine göre fındık, portakal, limon, mandalina ve çay ve emsali faydalı fidanların dikilmesine sahipleri mecburdur."

Buna göre birinci madde, fen memurlarının vereceği rapordan sonra, çalılık ve kızılağaçların kesilip koparılması ve yerlerine fındık, portakal, limon, mandalina ve çay dikilmesini mecbur etmektedir.

İkinci madde, hükümetçe, uygun bir yerde bir çay ve mandalina fidanlığı tesis edilmesini ve idaresinin bir uzmana verilmesini hükme bağlamaktadır. Üçüncü madde, dikilecek fidanların hükümetçe parasız olarak temin edileceğine dairdir. Dördüncü madde arazi sahiplerinin fen memurlarınca yapılacak tespitten sonra 3 yıl içinde fidan dikimini tamamlayacağına amirdir. Beşinci madde, süresi içinde dikim yapılan araziden on sene müddetle arazi vergisi alınmayacağını hükme bağlamaktadır (1924 tarih ve 407 sayılı Kanun).

Kanun teklifinde ve İktisat Komisyonu'nun TBMM Genel Kurulu'na gönderdiği metinlerde, kızılağaçların kesilmesi ve yerine; fındık, portakal, mandalina, limon ve çay dikilmesi için dekar başına 10 lira mükâfat verilmesi hükmüne yer verilmişti. Genel Kurul'dan ve İktisat Bakanı Hasan Bey'den (Saka) gelen itirazlar üzerine bu hüküm oylanarak reddedilmiştir. İktisat Komisyonu Başkanı ve İzmir Milletvekili M.Celal Bayar başta olmak üzere tüm Komisyonun mükâfat verilmesini savunduğu halde bunun reddedilmesi üzerine, 5 lira mükâfat verilmesi Rize Milletvekili Ekrem Bey ve İktisat Komisyonu'nca teklif edilmiş ancak o da reddedilmiştir.

1927 senesine gelindiğinde, kanunun 4.maddesindeki üç yıl içinde bahçelerin hazırlanması hükmüne rağmen bahçelerin oluşmadığı görüldüğünden, bu sürenin uzatılması gerekli görülmüştür. Kurulmuş olan Ziraat Bakanlığı tarafından söz konusu sürenin uzatılmasının hükümete teklif edildiği, 13 Şubat 1927 tarihli Bakanlar Kurulu'nda görüşülerek kabul edildiği ve kanun değişikliği için Başbakan İsmet İnönü imzasıyla TBMM'ye gönderildiği anlaşılmaktadır.

407 sayılı Kanun'da geçen üç yıllık süre 15 Nisan 1927'de sona ereceğinden, bu sürenin uzatılması talep edilmektedir. Gerekçe olarak; "Kızılağaçlıkların 1927 senesi Mart ayına kadar kesilmesi işinin tamamlanması takip edilmekte ise de halkın fakru zarureti ve araçlarının yetersizliği" sebepleriyle söz konusu süre içerisinde kesilemeyecekleri, bu sebeple 4. maddedeki sürenin üç sene uzatılması talep edilmektedir.

Ziraat Komisyonu'nun sürenin üç yıl daha uzatılmasını talep eden mazbatasında ise şunlar ifade edilmekteydi: "Mahallî halkın henüz harp ve darptan kurtulmuş olmaları dolayısıyla... gerçekte bitkilendirilmesi gereken 17.896,5 dönüme karşı hâlen üç bin küsur dönüm kadar bir mahallin portakal, çay ve emsali bitkilerle donatılabildiği anlaşılmıştı"” (TBMM Zabıt Ceridesi , 1927: 82).

Kurulan fidanlıkta yetiştirilen veya Batum'dan getirilen narenciye fidanları halk tarafından benimsendi ve narenciye bahçeleri oluşturuldu. Meyveleri yenilebilen ve alınıp satılabilen narenciyeye karşı, işlenmeden tüketilemeyen ve verime geçmesi için 4-5 yıl gereken çayda aynı başarı ortaya çıkmamıştır.

Ziraat Bakanı Muhlis Erkmen, 1940 yılında TBMM'ye sunulan Çay Kanunu Tasarısı'nın görüşmeleri esnasında yaptığı konuşmada, Rize'de 70 dekar büyüklüğünde bir fidanlık kurulduğunu ancak halkın çaya rağbet etmediğini ifade ederek; “... beş yıl sonra mahsul verecek olan çayın, kendisine ne gibi bir kazanç temin edeceğini tahmin edemediği için endişeli davranmakta haklı idi" demiştir (TBMM Zabıt Ceridesi, 1940: 9). 
Şevket Raşit Hatipoğlu Hoca'nın şu ifadesi, çayla ilgili gelinen durumu ortaya koymaktadır: "Çaylık kurma işine halk pek rağbet etmemiştir. Çay işi duraklamış ve devlet kendi fidanlığının dışına çıkamamıştır" (Hatipoğlu, 1939: 16). Bu durum, Kanun'dan mükâfat hükmünün çıkarılması ile ortaya çıkmıştır denilebilir.

1924 tarih ve 407 sayılı Kanun'un uygulanması esnasında Ziraat Genel Müfettişi sıfatıyla aralıklı olarak Rize'ye gelen Zihni Derin'in bu görevden alınması ve öğretmenlik görevine dönmesi çaycılık faaliyetlerine ara verilmesine yol açmıştır. Çaycılığın yeniden gündeme gelmesi, i̇smet İnönü’nün 1935 yılında Rize'yi ziyaretiyle mümkün olmuştur. O dönemde başbakan olan İnönü, doğu gezisinin dönüşünde Artvin üzerinden Hopa'ya ve buradan vapurla Rize'ye gelmiştir. Gezi notlarını "Doğu Raporu" veya "Kürt Raporu" adıyla ünlü raporunda kaydetmiştir.

"Rize temiz, şirin bir kasabadır. Son zamanlarda portakal, mandalina yetiştirmekte biraz geçim bulmuşlar. Şimdi bir ümitleri de çaydadır. Ziraat istasyon müdürü, çay için çok hevesli ve teşvikçidir" diye anlatan İsmet Paşa, "Rize'ye geçim bulmak, Karadeniz'in diğer kalabalık vilâyetleri gibi başlıca meselelerdendir" diye yazmıştır (Öztürk, 2016: 47).

1935 yılının Eylül ve Ekim aylarında, Samsun'dan Rize'ye kadar olan bölgenin “doğal, ekonomik ve sosyal şartlarını araştırmak üzere" bir inceleme gezisi yapan Tarım Bakanı Muhlis Erkmen'in bu gezisi sonrasında çay konusu yeniden etkili biçimde gündeme alınmıştır. (Saklı, 2008: 70).

Tarım Bakanı Erkmen'in talimatıyla, Prof. Dr. Şevket Raşit Hatipoğlu, çayla ilgili araştırma yapma görevini üstlenmiştir. Hatipoğlu, konuyu bütün yönleri ile ele alarak; "çay işinin doğal ve ekonomik şartlarını" Rize'de incelemiş, ülkenin çay tüketimi durumunu ve tüketim rakamlarını çeşitli yörelerden araştırmıştır. Bu araştırmalar sonucunda, "Türkiye'de Çay iktisadiyatı" adlı eseri meydana getiren Prof. Hatipoğlu, çay konusunu sadece tarımsal açıdan ele almamış; çay işleme teknolojisi, tüketim rakamları ve tahminleri ile çay ticaretini de kapsayacak şekilde ele almıştır (Hatipoğlu, 1939).

Çaycılık faaliyetlerine yeniden başlanan bu dönemde, 1921'den itibaren çaycılığın başında ve içinde bulunan Zihni Derin, tekrar işin başına getirilmiştir. Zihni Derin'in uğraşları ile BatumCakova'dan 1937 yılında 30.000 kg çay tohumu alınmış, bunlarla Rize'nin yedi yöresinde toplam 77 köyde, 300 adet çay fidanlığı oluşturulmuştur. Köylerde oluşturulan fidanlıklar, alan olarak 600 dekarı bulmuştur. Rize'de 1921 'den itibaren tesisine başlanan ilk çay fidanlığından başka, devlete ait iki çay fidanlığı daha tesis edilmiştir. Bunlar, 1937 yılında çay tohumu yetiştiren bir damızlık bahçesi olarak kurulan 110 dekarlık Hayrat fidanlığı ve 1938 yılında 108 dekar genişlikte kurulan (bugün Üniversite'nin Zihni Derin Yerleşkesi'ni oluşturan) Fener Mahallesi'ndeki fidanlıktır (Aktan, 1946: 63).

Faaliyetler yürütülmekte, ancak yasal bir zemine ihtiyaç duyulmaktadır. Çünkü yeni dönemde, Şevket Raşit Hatipoğlu'nun önerdiği (1939) ve Tarım Bakanlığı'nın kabul ederek program haline getirdiği bir destekleme uygulaması yapılmaktadır.

Ülkemizde çayla ilgili olarak Tarım Bakanlığı'nın ilk geniş çaplı çalışması, 1938 Ziraat Kongresi'ne sunulan ve Ziraat Genel Müdürlüğü’nce hazırlanan, “Meyvecilik-Bağcılık-Sebzecilik-Çay Genel Raporu ve Beş Senelik Program"dır. Bu belgeye göre çay tarımı, "hem arazisi dar ve geçim vasıtası sınırlı bir bölgenin ekonomik kalkınması, hem de dışarıya ödenen ve önemli bir yekûn tutan paranın ülke içinde kalması" amacıyla başlatılmaktadır (1938 Ziraat Kongresi: 107) 
Bu raporun 107-122 sayfaları arası çaycılığa ayrılmıştır. Raporda ülkemizin çay ihtiyacı, yılda 900 ton olarak tespit edildikten sonra, bunu elde etmek için 3000-4500 hektarlık çay bahçesi kurmak gerektiği belirtilmektedir. Programın ilk yılı olarak 1938-1939 verilmekte ve ilk yıl bir Çay Kanunu çıkarılması programda yer almaktadır.

Söz konusu program çerçevesinde Fiilen başlatılmış olan destekleme, 407 sayılı Kanun'un eksik bıraktığı kısmı tamamlamakta olduğundan başarılı sonuçlar hemen alınmaya başlanmıştır, ancak yasal uygulamanın hale getirilmesi gerekmektedir.

\subsection{Tarih ve 3788 Sayılı Çay Kanunu}

Uygulanmakta olan 'Beş Senelik Program'ın ilk yılında çıkarılması öngörülen Çay Kanunu, 07.07.1939 tarihinde TBMM'ye sunulduktan sonra, Rize'deki uygulama ekibinin de görüş ve katkıları ile uzun bir uğraştan sonra 27 Mart 1940'ta TBMM'de kabul edilmiştir.

407 sayılı Kanun gibi bir milletvekilinin teklifi olarak değil, Hükümet Tasarısı olarak TBMM'ye gelmiş olması daha başlangıçta bir farklılık oluşturmuştur. Bir başka farklılık, fiilen girişilen uygulamaya yasal bir zemin arayışı olarak ortaya çıkmasıdır. Nitekim Ziraat Bakanı Muhlis Erkmen'in görüşmeler esnasındaki şu ifadeleri durumu çok güzel anlatmaktadır:

"Çay fidanlığında bir kurutma evi (çay atölyesi) yapıp ta, yaprakları satın almaya başladığımız zamandan itibaren halk onun para ettiğini anlayınca ve görünce rağbet arttı ve müracaatlar birbirini takip etti. Bakanlık bundan sonra faaliyeti artırdı ve memleketin ihtiyacına tekabül edecek kadar 30.000 dekar çaylığı bir hamlede yapabilmek için lâzım gelen tedbirleri aldık. Evvela 2.000, sonra 30.000 ve bu yıl da 20.000 kilo tohum getirttik. 200 dekardan fazla bir tohum damızlık bahçesi yapıldı ve 77 köyde 300 müşterek fidanlıkta 15 milyondan fazla fidan yetiştirildi. Yalnız halkın buna rağbet göstermesi kâfi değildir. Çay bahçesi kurmak masraflıdır ve mahsul alıncaya kadar beş yıl beklemek lâzım geliyordu. O hâlde köylüye bu kazançlı şeyi temin edebilmek için ona maddî imkânı ve gücü de temin etmek lâzımdır" (TBMM Zabıt Ceridesi, 1940: 9).

Muhlis Erkmen'in ifadelerinden anlaşıldığı üzere; bu defa köylünün desteklendiği bir programla işe başlanmıştır. Halk geçim sıkıntısına çare olarak çayı görmeye başladığı anda, çay işi tutmuş ve olumlu gelişmeler ortaya çıkmıştır.

Kanun tasarısı, TBMM Ziraat, Adalet, Maliye ve Bütçe Komisyonlarında görüşüldükten sonra, söz konusu komisyonların değişiklik önerileri ile birlikte Genel Kurul'a gelmiştir. Hükümet gerekçesinde, yılda ortalama $973.950 \mathrm{~kg}$ çay ithal edildiği ve 870.638 lira (karşılı̆̆ı döviz) dışarıya ödendiği belirtilerek, halka 30.000 dekar çay bahçesi yaptırılabildiği takdirde, memleketin çay ihtiyacının tamamen karşılanabileceği görüşüne yer verilmiştir.

Ziraat Komisyonu'nun Kanun tasarısıyla ilgili mazbatasında su ifadelere yer verilmiştir: "Arazinin çok dar ve nüfusu en yoğun yörelerimizden biri olan ve geçim zorlukları bulunan Rize havalisinde kıymeti yüksek ürün yetiştirmek zarureti karşısında, çay ziraatının yaygınlaştırılması yolunda hazırlanan bu kanun tasarısını komisyonumuz sevinçle karşılayarak çok yerinde bulmuş, maddelerde yapılan ufak değişliklerle teklifi kabul etmiştir" (TBMM Zabıt Ceridesi, 1940: 4).

Maliye Komisyonu'nun mazbatasında, kendilerinin de kanun tasarısını sevinçle karşıladıklarını ifade ettikten sonra; "1924 tarih ve 407 sayılı kanunla mandalina ve portakal ziraatında 
büyük gelişmeler sağlandığı hâlde, çay gibi yeni bir ziraat türünün gelişmesi için fabrika kurulmasının, yasal teşvik ve yardımlarda bulunulmasının zarurî olduğu anlaşılmıştır" denilmiştir. Komisyon, yaptığı parasal değerlendirmede; "Her yıl bir milyon liraya yakın bir dövizin memlekette kalmasını temin edecek olan çay işinin Hazineye yüklediği külfet sadece yapılacak borçlandırmanın faizine tekabül ediyor" tespitinde bulunarak, Devlete önemli bir mali yük getirilmediği ifade edilmiş olmaktadır (TBMM Zabıt Ceridesi, 1940: 5).

18 Mart 1940'ta Çay Kanunu Tasarısı'nın TBMM'de görüşülmesine devam edilirken ilk sözü İzmir Milletvekili Halil Menteşe almış ve yerli çay satışının serbest olmasını; devlet tekeline tabi tutulmamasını istemiştir. Rize Milletvekili Ali Zırh söz alarak buna itiraz etmiş, sonra Ziraat Bakanı Muhlis Erkmen; "bölük pörçük ve perakende üretimlerle çay işinin akamete uğrayabileceğini" beyan ederek serbestleşmeye karşı çıkmıştır (TBMM Zabıt Ceridesi, 1940: 5-9). Çayda tekelin kaldırılması yönünde Halil Menteşe tarafından verilen teklif oylandı̆̆ında TBMM’de kabul edilmemiştir.

Kanun Tasarısı'nın maddelerine geçildikten sonra; birinci maddedeki "Çay bahçelerinin Ziraat Bakanlığı'nın tespit edeceği esaslar dairesinde kurulması ve bakılması mecburidir" hükmü tartışma yaratmıştır. Arazinin basamaklandırılması ve etrafının çevrilmesi gibi hükümler, ceza hükmü birlikte ele alınınca vatandaşın aşırı cezalara çarptırılabileceği endişesi ortaya çıkmıştır. Ziraat Vekili Erkmen "teknik esaslar" tabirinin konulmasının sorunu çözeceğini ifade etmiştir. Faaliyetlerin başında bulunan Ziraat eski Genel Müdürü Zihni Derin'e atıfta bulunmuş ve Kanun'un uygulanmasından kaygılanmaya gerek olmadığını beyan etmiştir.

3788 sayılı Çay Kanunu, Türkiye'de çay için özel olarak çıkarılan ilk Kanun olmanın yanında, ilk defa çay bahçelerinin ruhsatlandırılmasını (2.madde) da hüküm altına almıştır. Üçüncü madde; "Çay bahçesi kurulacak arazideki ağaç ve ağaççılar köklenerek çay bahçesi haline tahvil olunabilir" şeklindedir. Buradaki "köklenerek" ifadesinin ne anlama geldiği TBMM görüşmeleri esnasında soruldu, Orman Kanunu'ndaki hükümler sebebiyle "kesilmesi, koparılması, sökülmesi” tabirlerinin kullanılamadığı, köklenmesi tabirinin kökünün çıkarılması anlamına kullanıldığı bilgisi verilmiştir.

Dördüncü maddenin birinci bendinde; Ziraat Bakanlığı'nın çay tohumu, fidanı ve gübresini, dikimden itibaren 5 sene müddetle bedelsiz vereceği hükmü konulmuştur. İkinci bendinde ise yarım dekar veya 500 fidan için bir sene arayla üç defada 20'şer liraya kadar faizsiz borç verilmesi hükmü getirilmiştir. Başlangıçta dekar başına faizsiz borç verilmesi teklif edilmişken, arazinin kıt olması ve arazisi az olanların kanun hükmünden faydalanabilmesi için, teşvik yarım dönümle başlatılmıştır.

Beşinci maddede, 30.000 dekar çay bahçesi kurulana kadar sağlanacak borcun Ziraat Bankası'nca verilmesi hüküm altına alınmıştır. Bu borcun toplamda 1 milyon lirayı geçmemesi, bir sonraki sene Ziraat Bakanlığı bütçesine konularak faiziyle birlikte bankaya iadesi hükmü getirilmiştir.

Altıncı madde, halka verilen borcun, bahçeye tohum veya fidan dikiminin altıncı senesinin başından itibaren beş yılda, DZiK'e teslim edilecek yaş çay bedellerinden kesilmesi suretiyle tahsil edilmesini amirdir. Demek oluyor ki, devlet sadece borcun faizini yüklenmiştir.

Onuncu maddede çay yapraklarını satın alma, kurutma fabrikaları kurma, çay işleme harman yapıp paketleme ve satma-sattırma işleri DZiK'e görev olarak verilmiştir. Yine bu maddede; "Çay yapraklarını tespit edilen bedelle kurum almaya mecburdur" hükmü konulmuştur. 
Yaş çay fiyatının belirlenmesinde katılımcı ve demokratik bir yöntem belirlenmiştir. Kanunun onbirinci maddesinde; "Yaş yaprak fiyatları her yıl seçilecek 5 kişilik bir heyet marifetiyle tespit edilir" denilmektedir. Heyetin oluşumuna ilişkin hüküm ise; "Mahallî Ziraat Odası'nın seçeceği çay müstahsillerinden iki, Ticaret Odası'ndan bir, Ziraat Bakanlığı ve DZiK temsilcisi olan birer kişi" şeklindedir. İki çiftçi temsilcisi, iki devlet temsilcisi ve bir tüccar olmak üzere beş kişilik bir heyet oluşturulmuştur.

Sonraki hükümler ceza hükümleridir. Teknik esasa uygun çaylık kurmayanlara, aldıkları borcu ödemeyenlere, kurulmuş olan çaylığı sökenlere yüksek denebilecek cezalar içermektedir. Hele çaylık sökene 100 liradan 500 liraya kadar ağır para cezası konulmuştur.

Kanun'un geçici maddesi, şöyledir: "1939 malî senesinde DZiK'ten bu iş için ziraatçılara avans olarak verilen para Ziraat Bankası'ndan verilecek bir milyon liradan kuruma faizi ile birlikte iade edilir." Yani kanun çıkmadan önce ödenen avans da kanun kapsamındaki ödemeye dâhil edilmektedir.

10 Mayıs 1940 tarih ve 2/13450 sayılı Bakanlar Kurulu Kararnamesi ile 3788 sayılı Kanun'un uygulanacağı alan şöyle belirlenmiştir: "3788 sayılı Çay Kanunu'nun, memleketimizin iklim ve diğer vasıfları itibariyle çay ziraatına uygun mıntıkası olan Çoruh vilâyetinin Hopa kazasında, Trabzon vilâyetinin Sürmene ve Of kazalarında ve Rize vilâyetinin tamamında tatbik edilmesi (...) kabul olunmuştur." Kanun'un uygulama alanı, hemen hemen bugünkü çay yetiştirme bölgesini kapsamış gibidir. Günümüzde, Hopa'dan Araklı Deresi'ne kadar olan yöre birinci, Giresun'un bir ilçesi ikinci bölge olarak esas alınmaktadır.

\subsection{Tarih ve 4223 Sayılı Kahve ve Çay İnhisarı (Tekeli) Kanunu}

01.04.1933 tarih ve 14108 sayılı Bakanlar Kurulu Kararnamesi ile daha önce ithalatı tekele alınan kahve ile birlikte çay ithalinin de tekel marifetiyle yapılması kararlaştırılmıştı (14108 sayılı Kararname, 1933). 1938'den itibaren Rize'de çay üretimi başladığında, çaycılık faaliyetleri Devlet Ziraat Iş̧letmeleri Kurumu'na (DZiK) verilmiş, ancak çay ithalatında ve iç satışında tekel devam etmiştir.

21.5.1942'de TBMM'de kabul edilen ve 25 Mayıs 1942 tarihli Resmi Gazetede yayınlanan 4223 sayılı Kanun, kahve ve çayda Başbakanlık Kararnameleri ile devam etmekte olan fiili tekelin yasal temelini oluşturmuştur.

Kanun'un birinci maddesi: “Her nevi kahve ve çayın: a) istihlâk (tüketim) için Türkiye'ye sokulması; b) Çekirdek kahvenin kavrulmuş veya çekilmiş olarak satışı hariç olmak üzere, bu maddelerin gerek halliyle ve gerek şekli değiştirilmiş olarak yurt içinde satılması; Devlet inhisarı (tekeli) altındadır" hükmünü taşımaktadır. Yani çayın ithali ve ülke içinde satışı tekele alınmış, bu görev Tekel Genel Müdürlüğü’ne verilmiştir.

İkinci madde çay için özel bir hüküm içermektedir: "Türkiye dâhilinde yetiştirilen yaş çay yaprağının işlenmesi, kurutulması ve bu maksatla yaş çay yaprağının satın alınması Devlet tekeli altındadır. (Bu işler Devlet Ziraat İşletmeleri Kurumu tarafından görülür)." Bir sonraki madde ile her türlü kahve ve çay satışından alınacak asgari ve azami verginin Bakanlar Kurulu'nca belirlenmesi, maliyeti üzerine tekel vergileri eklenmek suretiyle perakende satış fiyatlarının tespiti Tekel Genel Müdürlügüne ve onayı Gümrük ve Tekel Bakanlığı'na verilmiştir. Maddenin sonuna; "perakende satışlar yurdun her tarafında aynı fiyatla yapılır" hükmü getirilmiştir.

Dördüncü maddede, tekel idaresinin markasını taşıyan kapalı kaplarda satılacak çay ve kahve için Tekel Genel Müdürlüğü’ne \%10 satış komisyonu ödeneceği, idare deposu olmayan 
veya şehir ve kasaba dışında olan yerlerdeki satıcılara nakil şartlarına ve uzaklığına göre bir nakliye ücreti verilebileceği hükme bağlanmıştır. Altıncı maddede, çay ve kahve satacak olanların tekel idaresinden ruhsat almaya mecbur oldukları hükmü konulmuştur.

Yedinci maddede; Dzik tarafından üretilen yerli çaylardan, ülkenin ihtiyacı kadar olan miktarının, maliyetine \%10 kâr ilave edilmesi suretiyle Tekel Genel Müdürlüğü tarafından satın alınacağı, çay maliyetlerinin nasıl tespit edileceğinin Gümrük ve Tekel Bakanlığı ile Ziraat Bakanlığınca ortaklaşa kararlaştırılacağı hükümlerine yer verilmiştir.

DZik tarafından halktan satın alınacak yaş çay yaprağı fiyatlarının nasıl belirleneceğine ilişkin 3788 sayılı Kanun'da yer alan hüküm değiştirilmiştir. Sekizinci maddede; “...yaş çay yaprağı fiyatları her yı mahallî ziraat odasının seçeceği çay müstahsillerinden iki, ticaret odasınca seçilecek bir ve Gümrük ve Tekel Bakanlığı'yla, Ziraat Bakanlığı ve Devlet Ziraat işletmeleri Kurumu ve Tekel Genel Müdürlügünce kendi memurları arasından seçilecek birer temsilciden oluşur" hükmü getirilmiştir. Buna göre, 1940'ta kabul edilen 3788 sayılı Kanun'da ikisi devlet görevlisi ikisi çiftçi temsilcisi ve bir kişide ticaret odası temsilcisinden oluşan bir kurul oluşmaktaydı. Sadece iki yıl sonra, 4223 sayılı Kanun'un 8.maddesi ile kuruldaki devlet görevlilerinin sayısı dörde çıkarılmış ve üçe karşı dört oyla devlet görevlilerinin çoğunluğu sağlanmıştır.

Kanun'un onuncu maddesi, bu kanunla tekel altına alınan maddelerin kaçakçılık fiilleri hakkında Kaçakçılığın Men ve Takibine dair kanun hükümlerinin geçerli olacağı hükmünü içermektedir. Günümüzde \%145 gümrük vergisi sebebiyle, ülkeye giren kaçak çaylarla çay piyasasının başı dertte olduğundan, burada alınmış olan tedbirler önemli görülmektedir. Buna göre, tekel maddeleri hakkında aşağıdaki fiilleri işlemek de kaçakçılık sayılmaktadır:

“a) Yaş çay yaprağının kanuni salâhiyeti olmayanlar tarafından işlenmesi veya kurutulmasi;

b) Terkibinde kafein ile birlikte tanen ve protein ve münhasıran çayın terkibinde bulunan diğer kimyevi maddeleri ihtiva etmeyen bitkilerin şahıslar tarafından şekilce çay taklit edilmek suretiyle işlenmesi ve kurutulması ve bu taklit çayların yurda sokulması, satılması, satılığa çıkarılması ve satmak kastiyle taşınması, saklanması, yanında bulundurulması ve bilerek satın alınması veya kabul edilmesi;

c) Yabancı maddelerle karıştırılmış kahve ve çayların gerek haliyle ve gerek pişirilerek satılması veya satılığa çıkarılması.

Kaçak kahvelerin her kilosu için (10) lira ve çaylarla diğer nebatların her bir kilosu için (20) lira ağır para cezası alınır. Kilodan az kesirler kilo sayılır ve kaçak olarak tutulan maddeler müsadere olunur ve bunlardan işe yaramayanlar müsadere kararı kesinleştikten sonra Tekel Idaresince yok edilir.

Kaçak maddelerin kaçakçı veya ortak ve yatakları gibi kaçakçılıkta iştiraki olan kimselerin elinden çıkmış olması veya bunlar tarafından tüketilmiş bulunması gibi sebeplerle müsaderesi kabil olmazsa kaçakçılardan yukarıdaki fıkrada yazılı para cezaları iki kat olarak alınır."(4223 Sayılı Kanun Md.10).

Yukarıdaki metinde dikkat çeken konulardan biri, çay kaçakçılığına kahve kaçakçılığının iki katı cezaya hükmedilmesidir. Bunun sebebi, ülkemiz içinde yetiştirilmekte ve işlenmekte olan çayın korunmasıdır. 
Çay sektörünün 1984'ten itibaren yaşanan serbestleşme sonrasında yaşadığı önemli sorunlardan birisi olan paket, marka ve bandrol taklidi ve kaçakçılığı olmuştur. 1942 tarihli incelediğimiz Kanun'da bu konuya ilişkin hükümler de dikkate çekicidir.

"Bu kanun ile tekel altına alınan maddelere Tekel idaresince konulan mühür, damga, farika veya kontrol alâmetleri, bandrol veya etiketleri taklit veya tahrif ederek konulduğu eşyadan kaldırarak, değiştirerek (veya her ne suretle olursa olsun tedarik ederek kaçak maddelerde kullananların hareketleri kaçakçılık sayılır ve haklarında 100 liradan 500 liraya kadar ağır para cezası hükmolunmakla beraber bu maddeler müsadere olunur ve bu suçun Türk Ceza Kanununda muayyen olan cezasıyla de ayrıca cezalandırılır.

Yukarıdaki fıkrada yazılı alâmet veya bandrol veya etiketleri salâhiyet veya mezuniyetleri olmaksızın basanlar veya satanlar veya saklayanlar hakkında 6 aydan 2 seneye kadar hapis cezasıyla birlikte 100 liradan 500 liraya kadar ağır para cezası da hükmolunur ve bu eşya müsadere olunur.

Bu maddede yazılı fiiller alâkalı memurlar tarafından işlenmiş ise bu cezalar iki kat olarak hükmolunur." (4223 Sayılı Kanun Md.14).

1984'ten sonra; bandrol, etiket ve paket taklitçiliğinden Çay İşletmeleri Genel Müdürlüğü önemli zararlara uğramıştı. Bu zararlardan kurtulmak için, çay paketleri üzerine taklit edilemeyen hologram etiket vurulmak suretiyle etkili bir çözüm bulunabilmişti. 1942' de bu fiillerde bulunanlar için hem ağır para cezası hem de hapis cezası konulmuş olması, konunun üzerinde ne kadar ciddiyetler durulduğunu göstermektedir.

Kanun'un uygulanmasıyla ilgili olarak; 25 Ağustos 1942'de çıkarılan 2/18662 sayılı Bakanlar Kurulu Kararnamesi ile kahve ve çay ithalatından alınacak tekel vergileri yeniden belirlenmiştir. Buna göre kahvenin kilosundan en az 300 en fazla 500 kuruş vergi alınmasına hükmedilirken, çay için 28 Şubat 1943'e kadar en az 500 en çok 1000, 1 Mart 1943'ten itibaren en az 750 en fazla 1000 kuruş tekel vergisi alınması hükme bağlanmıştır (2/18662 sayılı Kararname). Buradan anlaşıldığı üzere, kahveye oranla çaydan daha fazla ithalat tekel vergisi alınmakta ve bu suretle yerli çay sanayi korunmaktadır.

Daha sonra da çay piyasasının korunması için ithal edilen çaydan vergi alınmaya devam edilmiştir. 02.11.1946 tarih ve 3/4889 sayılı Bakanlar Kurulu Kararnamesi'nde ithal edilen çaydan en az 300 en fazla 500 kuruş vergi alınması kararlaştırılmıştır (3/4889 sayılı Kararname). 20.05.1949' da yine bir Kararname ile çay ithalinden kg başına en az 300 en fazla 1.500 kuruş vergi alınmasına karar verilmiştir (3/9357 sayılı Kararname).

1949 tarih ve 5433 sayılı Kanun'a kadar, çay tarımı ve imalatından DZik sorumlu iken, dağıtımını ve satışını Tekel Genel Müdürlüğü yürütmüştür. 7 Haziran 1949'da çıkan 5433 sayılı Kanun'la çay tarımı ve imalatı da Tekel Genel Müdürlüğüne verilmiştir.

\section{4. Çay İşinin Tekel Genel Müdürlüğü’ne Devredilmesi}

7.6.1949 tarih 5433 sayılı Kanun ile Devlet Üretme Çiftlikleri Genel Müdürlüğü kurulmuştur. Devlet Üretme Çiftlikleri Genel Müdürlüğü'nün görev ve yetkileri ile örgüt yapısını belirleyen Kanun'un 35.maddesi ile 3308 sayılı Devlet Ziraat işletmeleri Kurumu hakkındaki kanun kaldırılmıştır. 
Kanun'un Geçici 1.maddesi (c) bendi ile “Rize Çay Fabrikası ile buna ait bütün tesisler hariç olmak üzere Devlet Ziraat İşletmeleri Kurumu; bütün para ve para hükmündeki kıymet ve alacakları, işletmeden elde edilen gelir ve kıymetleri, menkul ve gayrimenkul malları, bütün hak ve menfaatleri ve her türlü taahhüt ve borçlan bunlara müteallik kayıt, defter ve belgelerle birlikte devredilmiştir." Bu Kanun'la DZik ortadan kaldırılırken, çay dışındaki bütün faaliyetleri ile birlikte yeni kurulan Devlet Üretme Çiftlikleri Genel Müdürlüğü’ne devredilmiş olmaktaydı.

Çay konusunda ise farklı bir durum ortaya çıkmıştır. Kanun'un Geçici 2. Maddesi; “Devlet Ziraat İşletmeleri Kurumuna ait Rize Çay Fabrikası, işletmeye taallûk eden para ve para hükmündeki kıymet ve alacakları, menkul ve gayrimenkul malları ve hak ve menfaatleri ve her türlü taahhüt ve borçlan ilgili kayıt, defter ve belgelerle birlikte Tekel Genel Müdürlüğüne devredilmiştir" hükmünü taşımaktadır.

Tarıma dayalı bir sanayi olarak gelişen çay faaliyeti, pazarlama ve satış kısmını yürütmekte olan Tekel Genel Müdürlüğü’ne devredilmiştir. Çaydaki asıl işin bir tarımsal faaliyet olarak görülmediği, daha çok bir sanayi ve ticaret faaliyeti olarak değerlendirildiği anlaşılmaktadır.

Çay faaliyetleri Tekel'e devredilmiş olmakla birlikte, çay tarım alanları ile ilgili konular Tarım Bakanlığı taşra örgütü tarafından yürütülmeye devam etmiştir. Ancak, 1971 yılında Çay Kurumu Genel Müdürlüğü'nün (Çaykur) kurulmasıyla, tarımı ve sanayisi ile çay faaliyetleri tek bir kuruma verilmiş olacaktır.

\subsection{0'li Yıllar ve Tarım Alanlarının Genişletilmesi}

Türkiye'de çay tüketimi hızla artmakta olduğundan, iç tüketimi karşılayabilecek üretimi sağlamak için yaş çay alanlarının genişletilmesi gerekli olmuştur. 3788 Sayılı Kanun'un 5.maddesi 30.000 dekar çaylık alan kuruluncaya kadar, çaylık yapanlara borç para verilmesi hükmünü taşımaktaydı. 27 Şubat 1950 tarihinde çıkarılan 574 Sayılı Kanunla çay tarım alanları 65 bin dekara yükseltilmiştir. 10 Temmuz 1953 tarih ve 6133 Sayılı Kanunla, çay tarım alanlarının genişletilmesi için Bakanlar Kurulu'na yetki verilmiştir.

6 Eylül 1955 tarih ve 4/3840 sayılı Bakanlar Kurulu Kararnamesi ile Giresun Merkez, Bulancak, Keşap, Tirebolu, Görele'de sahilden 15 km içeriye ve 500 metre yüksekliğe kadar çaylık kurulmasına izin verilmiştir.

22 Temmuz 1957 tarih ve 4/9290 sayılı Kararname ile Ordu Merkez, Perşembe ve Fatsa'da çaylık kurulması mümkün hale getirilmiştir.

13 Haziran 1966 tarih ve 6/6578 sayılı Kararname ile Maçka'ya bağlı Akköse, Kendi Güler, Tüfekçi, Ormancık, Çaybaşı, Taşçılar, Günebakan, Ulucami, Çalışanlar köylerine de çaylık kurma izni verilmiştir.

Bu arada 3 Şubat 1968 tarih ve 6/9603 Sayılı Kararname ile kayıt dışı 65 bin dönüm çaylığın kayda alınması uygun bulunarak bölgede çay tarımı yapılan toplam alan 265 bin dekara yükseltilmiştir.

Mevcut çay yetiştirilen alanlara bakıldığında; Ordu ve ilçeleri ile Maçka ve köylerinde çay yetişmediği görülmektedir. Giresun'un Tirebolu ilçesi etrafındaki iklim müsait olduğundan, burada çay yetişmekte ve Çaykur'a ait bir adet yaş çay işleme fabrikası Tirebolu'da faaliyette bulunmaktadır.

Çay tarım alanları 1973 yılında 404 bin dekara, 1983 yılında ise 644 bin dekara ve 1990 yılında da 906 bin dekara kadar çıkmıştır. 


\subsection{0'li Yıllar ve Çay Kurumu'nun Kuruluşu}

İktisadi Devlet Teşekkülleri, Müesseseleri ve İştirakleri hakkındaki 440 Sayılı Kanun'a uygun olarak 6 Aralık 1971 tarihli ve 1497 Sayılı “Çay Kurumu Kanunu” ile Çay Kurumu adı altında, "tüzel kişiliğe sahip, çalışmalarında özerk, sorumluluğu sermayesiyle sınırlı bir İktisadi Devlet Teşekkülü" kurulmuştur.

Trabzon Milletvekili Ahmet Şener başta olmak üzere, Rize Milletvekili Sami Kumbasar, Trabzon Milletvekilleri Ali Rıza Uzuner, C. Küçük, M. Arslantürk ve diğer çay bölgesi dışı milletvekillerinin imzasıyla, merkezi Ankara'da olmak üzere Çay Kurumu kurulmasını ihtiva eden kanun teklifi verilmiştir (1497 sayılı Kanun Teklifi). O dönemde ikili meclis mevcut olduğundan, teklif Cumhuriyet Senatosu'na gittiğinden Rize Senatörü Osman Mecdi Agun'un teklifiyle merkezi Rize olarak değiştirilmiş ve tekrar Millet Meclisi'ne geldiğinde de tüm yöre milletvekillerinin desteğiyle bu şekilde geçmiştir (Kumbasar, 2014). Kanun teklifinin gerekçesindeki aşağıdaki ifade önemlidir:

"Memleket çay üretiminin çay ihtiyacını karşılayacak dereceyi bulmuş olmasına karşılık çayın yetiştirme ve işlenmesinin ayrı idarelerde (Tarım - Tekel) bulunması, üretim ile işlemenin aynı ölçüde yürütülememesi, çay fabrika ve atölyelerinin mevcut çay yapraklarını işleyecek kapasitede bulunmaması, işlemenin biyolojik ve teknik esaslara uygun olarak yapılamaması ve çay ambar ve ambalaj tesislerinin bugün de kurulamamış halde bulunması, memleket çaylarının bileşimi ve niteliği üzerinde büyük ölçüde tesir yapmaktadır." (1497 sayılı Kanun Teklifi).

Çay Kurumu'nun en önemli kuruluş gerekçesinin; çay tarımının başka çay işleme ve pazarlamasının başka bir birime verilmesiyle ortaya çıkan olumsuz durumun ortadan kaldırılmasının ana gerekçeyi oluşturmasıdır. Çayın bileşimi ile ilgili kaygının, iç tüketimin henüz karşılanamadığı 1962 yılına kadar, Tekel tarafından Türk çayının \%50 oranında Hint ve Seylan çayları ile karıştırılıyor olmasına atıf yapılarak izah edilmesi de önemlidir. Demek ki, Çay Kurumu'nun kurulmasıyla, iç tüketimin rahatça karşılanacağı üretim düzeylerinin sağlanması beklentisi de söz konusudur.

Bilindiği gibi Kamu İktisadi Teşekkülleri (KiT’ler), Kamu Iktisadi Kuruluşu (KiK) ve İktisadi Devlet teşekkülü (IDT) olmak üzere ikiye ayrılır. Kik'ler tekel niteliğinde mal ve hizmet üreten kamu kuruluşları iken, iDT'ler ticari mal ve hizmet üreten kamu işletmeleridir. Çay Kurumu'nun (Çaykur) kurulduğu dönemde henüz özel sektöre çay üretim ve pazarlama izni verilmemiş olduğundan, tekel mahiyetinde bir kuruluş olduğu halde IDT statüsünde kurulmuştur.

Söz konusu kanun ile 4223 sayılı Kahve ve Çay İnhisarı Kanunu'nun birinci maddesinde mevcut çay tekeli, 3788 sayılı Çay Kanunu'nun ikinci maddesindeki ruhsat verme yetkisi ile 5433 sayılı Kanun'un ikinci maddesinin ikinci fıkrası ile Tekel Genel Müdürlüğü’ne verilen görev ve yetkiler Çay Kurumu'na devredilmiştir.

Üçüncü maddenin birinci bendinde; “üreticiden, işletmeye uygun nitelikteki çay yapraklarını tekeli altında satın almak, ikinci bendinde; "satın alınan çay yapraklarını işlemek ve değerlendirmek için teknolojik faaliyette bulunmak" Çaykur'un faaliyet konuları olarak belirlenmiştir. Üçüncü bentte ise, yukarıdaki faaliyetlerle ilgili olmak üzere; gerekli tesisler kurmak ve işletmek, araştırma faaliyetleri yapmak, bunun için gerekli müessese ve laboratuvar kurmak, gerekli madde ve araçları tedarik etmek, ticaretle uğraşmak, çay üreticilerinin kooperatifleşmesi için 
gerekli faaliyette bulunmak ve gerekirse bir eksperlik okulu açarak çay eksperi yetiştirmek görevlerine yer verilmiştir.

Dördüncü maddede, "Teşekkülün kuruluş amacl; memleketin tanım politikasına uygun olarak çay ziraatını geliştirmek, çay kalitesini ıslah etmek ve işletmesini teknik esaslara göre yürütmek, iç ve dış pazar isteklerine uygun mahsul üretimini sağlamaktır" ifadesine yer verilmiştir. Sermaye birikimine yardım etmek, yatırım kaynağı yaratmak, verimlilik ve kârlılık anlayışı içinde faaliyet yürütmek amaçlar arasında yer almıştır.

Tamamı devlete ait 1 milyar TL sermaye ile kurulan Çaykur'un, biri genel müdür, ikisi genel müdür yardımcısı olmak üzere, Ziraat Odaları Birliği'nden bir, Çay Üreticileri Yardımlaşma Kooperatifi birliğinden iki üye ve üç bakanlık temsilcileri olmak üzere 9 kişilik yönetim kurulu oluşturulmuştur.

Kanun'un 11.maddesinde; 30 adet alt bentte olmak üzere yönetim kurulu yetkileri genişçe tanımlanmış, 14.maddede ise genel müdürün yetkileri 9 alt bentte belirlenmiştir. Çay Kurumu Kanunu 30 madde 4 geçici maddeden oluşmuş olan, kapsamlı bir kanun niteliğindedir.

1971 yılında çıkan 1497 sayılı Çay Kurumu Kanunu’na dayalı olarak 1973 yılında kurulan Çay Kurumu, çay sektöründe daha önce farklı kurumlarda olan yetkilerin tek merkezde birleştirilmesini sağlamıştır. Ayrıca, Tekel Genel Müdürlüğü'nün tütün ve içki gibi farklı alanlardaki faaliyetleri, çay konusu üzerinde yoğunlaşılmasını engellemekteydi. Yeni dönemde çay sektörünün Rize'den ve tek merkezden idaresi söz konusu olduğundan, sektördeki en hızlı büyüme ve üretim artışları bu dönemde meydana gelmiştir.

1983 yılında, 2929 sayılı Kanun yasalaşmıştır. Bu Kanun, 440 sayılı Kanunu ve 1497 sayılı Çay Kurumu Kanunu'nun kendisine aykırı düşen; yönetim kurulunun oluşumuyla ilgili maddelerini yürürlükten kaldırmıştır.

1983 yılında çıkartılan 2929 sayılı kanunla Çay Kurumu, Çay İşletmeleri Genel Müdürlüğü adını almış ve Kamu İktisadi Kuruluşu statüsüne dâhil edilmiştir. KiT’ler için genel bir düzenleme olan Kanun'un 6.maddesi ile Kiт yönetim kurulları bir başkan ve dört yönetim kurulu üyesinden oluşturulmuştur. Teşekkül bünyesinden sadece Genel Müdür, Yönetim Kurulu Başkanı olarak kurulda yer almıştır. Diğer dört üyeden üçü ilgili Bakanlık tarafından biri de Maliye Bakanlığı'nca atanacaktır.

KiT'lerin kuruluşu ile ilgili tüm KHK'lar gibi 1497 sayılı Çay Kurumu Kanunu ile 1983'te çıkarılan 2929 sayılı Kanun, 1984'te çıkarılan 233 sayılı KHK ile yürürlükten kaldırılmıştır. Çaykur, Kamu İktisadi Teşebbüslerini yeniden düzenleyen 233 sayılı Kanun Hükmünde Kararname kapsamına alınmıştır. 233 sayılı KHK ile KiT yönetim kurulları bir başkan ve beş üye olarak altı kişiden teşkil edilmiştir.

IDT olarak kurulduğu halde, 1983 yılında KiK haline getirilen Çaykur, 24.11.1994 tarih ve 4046 sayılı Özelleştirme Uygulamaları Hakkında Kanun'un 35/a maddesiyle İktisadi Devlet Teşekkülü (IDT) statüsüne alınmıştır. Özelleştirme ile ilgili Kanun'da bu değişikliğin yapılmasının nedeni, KiK'lerin özelleştirilmesi için yasal düzenleme gerekirken, iDT'lerde Yüksek Plânlama Kurulu Kararı'nın yeterli olmasıdır. Zaman zaman özelleştirme kapsamına alınmakla birlikte, birçok özel sektör işletmesinin başarılı bir işletmecilik yapamaması sebebiyle Çaykur'a olan intiyaç devam etmiş ve etmektedir.

Çay İşletmeleri Genel Müdürlüğü Ana Statüsü 20.12.1996 tarih ve 22853 sayılı Resmi Gazetede yayımlanarak yürürlüğe girmiştir. KiT’lerde özerklik bir konuya verildiği için, Çaykur'un Ana 
Statüsü; "hukuki bünye, amaç ve faaliyet konuları, organları ve teşkilât yapısı, müessese, bağlı ortaklık ve iştirakleri ile bunlar arasındaki ilişkileri” belirleyen bir metin durumundadır.

233 sayılı KHK ve Ana Statüsünde saklı tutulan hususlar dışında özel hukuk hükümlerine tabi olan Çaykur, 6085 sayılı Sayıştay Kanunu'nun 43'üncü maddesi uyarınca Sayıştay ve 3346 sayılı kanun uyarınca da TBMM denetimine tabidir.

\subsection{Serbestleştirmesi (Deregülasyon) ve Sonuçları}

4.12.1984 tarih ve 3092 sayılı Çay Kanunu, Türkiye'de başlangıcından beri tekel mahiyetinde olan çay üretimi, işletmesi ve satışını özel sektöre açmıştır. Söz konusu Kanun'un birinci maddesi şöyledir:

"Çay tarımı, üretimi, işletmesi ve satışı bu Kanun hükümleri dairesinde serbesttir. Gerçek ve tüzelkişiler yaş çay işleme ve çay paketleme fabrikaları kurup, işletebilirler, ihtiyaçları olan yaş çay yaprağını doğrudan üreticiden satın alabilirler."

Çayda özel sektöre faaliyet izni veren bu madde; çay üreten ülkelerdeki mevcut yapılar, özel sektörün başarı koşulları vb gibi incelemeler yapılmadan, her bakkal ve markette satılan, her çay ocağında kullanılan bu ürünün piyasa mekanizmasına bırakılmasının sorunları çözeceği kabulü ile çıkarılmıştır. Ancak uygulama bunun tam tersi bir sonuç vermiş ve sektörde büyük sorunlar ortaya çıkmıştır.

Kanun'un ikinci maddesi çay tarım alanlarını sınırlamakta, ruhsatsız çay bahçesi kurulmasını yasaklamakta ve bu konuda cezai hükümler getirmektedir. Üçüncü madde ise daha önceki çayla ilgili bazı kanunları ve hükümleri yürürlükten kaldırmaktadır. Maddenin ifadesi şöyledir: “27.3.1940 tarihli ve $3788,20.5 .1942$ tarihli ve 4223, 4.7.1953 tarihli ve 6133 sayılı kanunlar ile 9.2.1340 tarihli ve 407, 7.6.1949 tarihli ve 5433 sayılı kanunların çayla ilgili hükümleri yürürlükten kaldırılmıştır."

Kanun'un dördüncü ve beşinci maddeleri yürürlük ve yürütme maddeleridir. Çayla ilgili önceki kanunlar daha kapsamlı ve uzun olduğu halde, 3092 sayılı Kanun; ikisi çay konusu ile ilgili hüküm içeren 5 maddeden oluşmaktadır. Üstelik üçüncü madde ile diğer bazı çay kanunları ve bazı çayla ilgili hükümleri kaldırılmaktadır.

Bu uygulama, 1980'li yıllarda İngiltere Başbakanı Margaret Thatcher ve ABD Başkanı Ronald Reagan'ın başını çektiği, Türkiye Başbakanı Turgut Özal'ın da önde gelen uygulayıcılarından olduğu yeni sağ ekonomik anlayışın bir yansımasından başka bir şey değildir. Özelleştirmeler, devletin küçültülmesi (minimal devlet anlayışı), kamu kaynaklarının verimli kullanımı gibi içeriklere sahip olan bu yeni anlayışın bir uygulamasını da serbestleştirme olarak tercüme edebileceğimiz; deregulasyon oluşturmaktadır.

Çay sektöründe özel sektöre faaliyet izni veren 3092 sayılı Çay Kanunu'nun çok az madde ve hüküm içermesi, bunun yanında eski kanun ve hükümleri de yürürlükten kaldırması, tam bir serbestleştirme uygulaması ile karşı karşıya olduğumuzu göstermektedir.

Özel sektöre çay üretimi, işletmesi ve satışı ile ilgili izin verilmesiyle birlikte, 1985 yılında çayda özel sektör faaliyetleri başlamıştır. Yeşil çay yapraklarının bir işleme sürecinden sonra kullanılabilir ve tüketilebilir hale gelmesi sebebiyle, özel sektörün faaliyete başlaması ancak çay işleme tesisi kurması ile mümkün olabilmekteydi.

Çay müstahsili ve çoğu çay işleme fabrikası işçisi olan yöre halkı, çay işleme fabrikalarındaki üretim aşamalarını iyi bilmekteydi. Bu sebeple yeni çay işleme atölye ve fabrikaları kurmak onlar 
için hiç zor olmamıştır. Başta Rize olmak üzere, Artvin ve Trabzon illerinin çay yetiştirilen bölgeleri de dâhil edilmek kaydıyla, emsali az görülebilecek bir girişimcilik olayına sahne olmuştur. Çaykur'un o tarihteki 45 fabrikasına karşılık, 1993 yılına gelindiğinde özel sektör tarafından 312 çay atölye veya fabrikası kurulmuştur. Halk bir araya gelerek köyünde, mahallesinde, beldesinde çay işleme tesisi kurmaya girişmiştir (Saklı, 2004).

Çay işleme tekniğini bilen halk çok sayıda çay işleme atölyesi ve fabrikası kurmayı başarmış, ancak bunları başarılı biçimde çalıştıramamıştır. Çay paketlemesi, pazarlama, reklam, tanıtım, tutundurma gibi faaliyetleri bilmeyen insanlar, yeşil yaş çay yapraklarını birçoğu ilkel teknoloji kullanan tesislerde işleyip siyah çaya dönüştürmüş, ancak devamını getirememiştir. Bunun sonucunda 1993'e kadar 144 çay işleme tesisi kapanmıştır (Saklı, 2004, Saklı, 2008).

Hindistan, Sri Lanka ve Kenya gibi önde gelen çay üreticisi ülkelerde, çay sektörünü yöneten Çay Kurulu ve üretilen siyah çayın dağıtıcı ve paketlemecilere açık artırma ile satıldığı Çay Borsası standart kurumlardır. Ülkemizde bu kurumlar oluşturulmadan girişilen serbestleştirme uygulaması olumsuz sonuçlanmıştır. Çay Kurulu kurulmadığı için, kabaca \%50'sine Çaykur'un hâkim olduğu sektörün kamu ve özel olarak bütününü kapsayacak politikalar belirlenip uygulanamamaktadır. Çay işleme tesislerinin paketleme ve pazarlama sorunlarını ortadan kaldıran Çay Borsası'nın kurulmaması, şirket iflaslarını ve fabrika kapatmalarını beraberinde getirmiştir (Saklı, 2004, Saklı, 2008).

Çaykur' un yaş çay bedellerini ödemedeki gecikmelerini kullanan özel sektör, zaman zaman üreticiye peşin ödeme vaadleriyle hızlı bir ürün alımı yapmıştır. Ancak, kuru çay satışında yılların markasının (Çaykur'un) olduğu bir pazara girdiklerini dikkate almamaları nedeniyle, özellikle küçük işletmelerin iflası çok hızlı gerçekleşmiştir. Özel sektör ürünlerinin perakende satışlarındaki düşüklük, para dönüşünü geciktirmiş olup, bu durum üreticiye para yerine işlenmiş çay verme uygulamasını da beraberinde getirmiştir.

Rize Ticaret Borsası'ndan alınan bilgilere göre, günümüze kadar kurulan atölye ve tesislerden, çay işleme sezonunun başladığı her yılın Mayıs ayında, yaş çay satın almaya girişen veya çay işlemeye hazır durumda olan tesis sayısı Rize'de 120-130, çay bölgesinin tamamında ise 170 civarındadır.

3092 sayılı Kanun'la girişilen serbestleştirme ile özel sektöre izin verilmesi, yeni sağ ve neoliberal yaklaşımla incelendiğinde; hantal ve verimsiz bir KiT olan Çaykur'un, yüksek teknoloji kullanacak, Ar-Ge yapacak, verimli ve kârlı çalışacak bir özel sektör karşısında şansının olmayacağı beklentisinin var olduğu düşünülebilir. Ancak bu beklenti gerçekleşmemiş ve tam tersi sonuçlar ortaya çıkmıştır.

ilk dönemlerde, Çaykur'un paketleri geniş ölçüde taklit edilerek bir haksız rekabet ortamı oluşmuştur. Çaykur, bir taraftan yasal yollara başvurarak, diğer taraftan paketler üzerinde taklit edilemeyen hologram etiket kullanmak suretiyle sorunu ancak kontrol altına alabilmiştir. Çaykur'un ürün çeşitliliğini arttırması da özel sektörün pazar payını daraltmıştır.

Yaşanan bir başka sorun, özel sektör yaş çay işleme tesislerinin müstahsile yaş çay bedeli ödemede aşırı biçimde gecikmeleri olmuştur. Tesis ve atölyelerin faaliyete devam edemeyip kapanması durumunda, yaş çay üreticisinin alacakları yargı ve icra süreçlerine kalmış, çoğunlukla da yaş çay bedellerinin tahsili mümkün olamamıştır.

Birçok fabrika ve tesis kapatmalarından sonra, zaman içinde güçlü olanların ve kaliteli çay üretenlerin ayakta kaldığı çay özel sektörü, giderek eksiklerini gidermekte ve kaliteyi artırma yönünde önemli adımlar atmaktadır. 
Dünya çay borsası anlayışını bir tarafa bırakarak; gönüllü katılıma dayalı ve lisanslı depoculuktan bağımsız biçimde Rize Ticaret Borsası içinde kurulmaya çalışılan Çay Borsası, talep yetersizliği ve arz azlığı gibi sebeplerle dar bir sektörel paya istinat ettiğinden yeterince başarılı olamamaktadır.

3092 sayılı Kanun'un 2.maddesine dayanılarak, Çay Bahçesi Kuracak Olanlara Ruhsatname Verilmesinde Uygulanacak Esaslara Dair Yönetmelik çıkarılmıştır. Toplam 13 maddelik kısa Yönetmelik'le çaylık alanların ruhsatlandırılmasına ilişkin kurallar belirlenmiş ve Çaykur'un uygulamayı nasıl yapacağı tespit edilmiştir.

Sektördeki önemli uygulamalardan bir başkası, Ulusal Çay Konseyi kurulması olmuştur. 2008 yılında çıkarılan Ulusal Çay Konseyinin Kuruluşu ile Çalışma Usul ve Esasları Hakkında Yönetmelik, Ulusal Çay Konseyi'nin çalışma yöntemlerini belirlemiştir.

Zorunlu uygulama yapma yetkisi olmayan Konsey, "yaş çay üreticileri ile yaş çay bitkisinden elde edilen asıl ve yan ürünlerin ticaretini yapan tüccarlar, sanayiciler ve/veya bunların oluşturdukları birlikler, dernekler, kooperatifler ve birlikleri ile çay bitkisiyle ilgili araştırma ve eğitim kurumları, meslek odaları ve sivil toplum kuruluşlarının" bir araya gelerek kurdukları bir organdır. Sektörün tamamını kapsayacak politikaların belirlenmesi ve uygulanması noktasında işlev üstlenebilecek Ulusal Çay Konseyi'nin, yeterince güçlü olmaması ve yaptırım gücünün bulunmaması rolünü kısıtlamaktadır.

\subsection{0'li Yıllar; Yasalaşmayan Çay Kanunu Hazırlığı}

2008'de Ulusal Çay Konseyi'nin kurulması ve başına dönemin Rize Milletvekili Ali Bayramoğlu'nun geçmesi, çay konusunda yeni bir yasa çıkarılması hazırlığını beraberinde getirdi. Ulusal Çay Konseyi ve Rize Ticaret Borsası bir çalışma grubu oluşturarak, geniş bir çay yasası hazırlanması için çalışma başlattı. 2009 yılında başlatılan çalışmanın sonucunda bir yasa taslağı ortaya çıktı.

Yeni yasa taslağı, dört noktada yeni uygulamalar getirmekteydi. Bunlar; çay kurulunun kurulması, çay borsasının oluşturulması, çay işleme fabrikalarına yaş çay kotası verilmesi, yasa dışı ve kurallara aykırı hareket edenlere aşırı cezalar verilmesi şeklinde özetlenebilir (Saklı, 2011).

Rize Ticaret Borsası, (2019) web sitesinde bir metnine yer verilen taslak, Hindistan, Sri Lanka ve Kenya'da başarılı olmuş bir yapıyı Türkiye'ye getirmeye çalışıyordu. Bu yapının temelinde; çay borsası ve çay kurulu etrafında sektörün yapılandırılması yatmaktaydı. Farklı olarak yaş çay işleme fabrikalarına kota verilmesi metne dâhil edilmişti.

Çaykur, tüm çayın çay borsada satılması zorunluluğu kuralı karşısında, çay borsasının yasa taslağı metninden çıkarılmasını istedi. Çaykur'un eleştirileri ve güçlü özel sektör firmalarının paketli çaylarının borsa dışında satma talebi dikkate alınarak tüm çayın çay borsasında satılması zorunluluğu taslaktan çıkarıldı (Saklı, 2011).

Zamanın Çay Konseyi Başkanı Ali Bayramoğlu’nun özel sektör çay fabrikasına sahip olması, tasarının bir özel sektör yaklaşımı olarak görülmesine neden oldu. Çaykur'un karşı duruşu yanında, toplumsal desteğin sağlanamaması ve iktidar partisinin yerel birimlerinin destek vermemesi sonucu bu teşebbüs hayata geçirilememiştir.

1924'teki 407 sayılı çayla ilgili ilk kanundan itibaren çıkarılan yasaların kronolojisi ve içerik özetleri aşağıdaki Tablo'da verilmiştir. 
Tablo 1: Türkiye'de Çıkarılan Çay Yasaları Kronolojisi

\begin{tabular}{|c|c|}
\hline Çıkarılan Yasa ve Mevzuat & Mevzuat İçeriği \\
\hline $\begin{array}{l}\text { 06.02.1924 Tarih ve } 407 \text { Sayılı Rize Vilâyetiyle } \\
\text { Borçka Kazasında Fındık, Portakal, Limon, Man- } \\
\text { dalina ve Çay Yetiştirilmesi Hakkında Kanun. }\end{array}$ & $\begin{array}{l}\text { Yasa ile Rize ve Borçka'da yaşayan halka, fındık, portakal, limon ve man- } \\
\text { dalina yanında ücretsiz çay tohumu ve çay fidanları dağıtılmıştır. }\end{array}$ \\
\hline 02.04.1940 tarih ve 3788 Sayılı Çay Kanunu. & $\begin{array}{l}1938 \text { 'de yeniden başlatılan çaycılık faaliyetlerine yasal altyapı sağlan- } \\
\text { mıştır. }\end{array}$ \\
\hline $\begin{array}{l}\text { 25.05.1942 Tarih ve } 4223 \text { Sayılı Kahve ve Çay } \\
\text { İnhisarı Kanunu }\end{array}$ & $\begin{array}{l}1933 \text { 'ten itibaren çay ithalatı, } 1938 \text { 'den itibaren çay iç satımı tekele alın- } \\
\text { mıştı. Yasa ile mevcut tekel yasal teminat altına alınmıştır. }\end{array}$ \\
\hline $\begin{array}{l}\text { 7.6.1949 tarih } 5433 \text { sayılı Devlet Üretme Çiftlik- } \\
\text { leri Genel Müdürlüğü Görev ve Kuruluş Kanunu }\end{array}$ & $\begin{array}{l}\text { 1938'den 1949'a kadar çaycılık faaliyetlerini yürüten Devlet Ziraat İşlet- } \\
\text { meleri Kurumu kapatılmış, çay işi Tekel Genel Müdürlüğü'ne verilmiştir. }\end{array}$ \\
\hline 27 Şubat 1950 Tarih ve 574 Sayılı Kanun & Çay tarım alanları 65.000 dekara çıkarılmıştır. \\
\hline 10 Temmuz 1953 tarih ve 6133 Sayılı Kanun & $\begin{array}{l}\text { Çay tarım alanlarının genişletilmesi için Bakanlar Kurulu'na yetki veril- } \\
\text { miştir. }\end{array}$ \\
\hline $\begin{array}{l}6 \text { Aralık } 1971 \text { tarihli ve } 1497 \text { Sayılı Çay Kurumu } \\
\text { Kanunu }\end{array}$ & Çay Kurumu adı altında bir İktisadi Devlet Teşekkülü kurulmuştur. \\
\hline $\begin{array}{l}112 \text { sayılı Çay İşletmeleri Genel Müdürlüğü ku- } \\
\text { ruluşu hakkında Kanun Hükmünde Kararname } \\
\text { (18.10.1983 tarih ve } 18195 \text { sayılı Resmi Gazete) }\end{array}$ & $\begin{array}{l}\text { Çay Kurumu'nun adı Çay İşletmeleri Genel Müdürlüğü olarak değişmiş } \\
\text { ve bir Kamu İktisadi Kuruluşuna dönüştürülmüştür. }\end{array}$ \\
\hline 4.12.1984 tarih ve 3092 sayılı Çay Kanunu & $\begin{array}{l}\text { Tekel mahiyetinde olan çay üretimi, işletmesi ve satışı özel sektöre açı- } \\
\text { mıştır. (Serbestleşme; deregulasyon). }\end{array}$ \\
\hline $\begin{array}{l}\text { 24.11.1994 tarih ve } 4046 \text { sayılı Özelleştirme Uy- } \\
\text { gulamaları Hakkında Kanun }\end{array}$ & $\begin{array}{l}\text { Çaykur'un Kamu iktisadi Kuruluşu olma vasfına son verilerek, iktisadi } \\
\text { Devlet Teşekkülü (IDT) statüsüne alınmıştır. }\end{array}$ \\
\hline 19 Ağustos 2016 & $\begin{array}{l}\text { Çay İşletmeleri Genel Müdürlüğü, Türkiye Varlık Fonu Anonim Şirketine } \\
\text { devredilmiştir. }\end{array}$ \\
\hline
\end{tabular}

Tablo 1'de çay yasalarının kısa bir kronolojisine yer verilmiştir. Bazen önemli yetkilerin Bakanlar Kuruluna verildiği gözlenmekte, çaylık alanlarının genişletilmesi gibi önemli konular kararnamelerle hüküm altına alınabilmektedir. Metin içinde yapılan incelemelerde bunlara yer verildiği halde, kronolojiye alınmalarına gerek görülmemiştir.

\section{Sonuç ve Değerlendirme}

Cumhuriyetin ilk yıllarından itibaren, Rize'nin geçim sorununu hafifletebilmek için kanunlar çıkarılmış ve en önemli kanun konusu da çay olmuştur. 1924'te çayın yanında; portakal, mandalina, limon, fındık, bambu gibi başka bitkilerle çay aynı kategoride değerlendirilerek desteklenmiştir. Bu dönemde, diğer ürünlerin Rize'de ve bölgede yetiştirilmesinde başarılı sonuçlar alındığı halde, çay yetiştirilmesinde aynı başarı ortaya çıkmamıştır.

Bunun nedeni, çayın işlenmeden tüketilememesi ve işleme tesisleri kurulmadan üretilen çayın ne olacağı ve yaş çay bedelinin nasıl ödeneceği noktasında, halkın aydınlatılamamasıdır. 1924 tarih ve 407 sayılı Kanun'da, bahçe tesisinde dekar başı 10 lira ödül verilmesi kanunda yer alsaydı, bu bedeli almak için çaylıklar tesis edilebilirdi. Bu da mümkün olmayınca, çayın Rize'ye yerleşmesi fiili olarak ertelenmiş olmaktaydı.

Şevket Raşit Hatipoğlu'nun Türkiye'de Çay İktisadiyatı başlıklı çalışmasından sonra, çay için neler yapılması ve nasıl bir program takip edilmesi gerektiği açıklığa kavuşmuştur. 1938' de Zihni Derin tekrar çay örgütünün başına getirilmiştir. Bu defa atölyeler kurularak yetiştirilen yaş çayın işlenmesi mümkün hale geldiği gibi, halkın ürettiği yaş çay bedeli mukabili satın alınabilmiştir. Kurulan bu sistem ve yeni uygulama, 1940 tarih ve 3788 sayılı Kanun'la teminat altına alındığından, çay tarımı Rize'de kalıcı olarak kendine yer bulmuştur. Bundan sonra, iç talebi karşılayacak seviyede siyah çay üretimini sağlamak üzere, çay bahçesi tesis edilebilecek alanların sürekli genişletilmesi ve yeni çaylıklar tesis edilerek üretimin artırılması hedeflenmiştir. Aynı şekilde, üretilen yaş çayın işlenebilmesi için fabrikalar kurulması gerekli olmuştur. 
1963 yılından itibaren iç talep yerli üretimle karşılanabilmiş ve çay Türkiye'nin milli içeceği haline gelmiştir. Çayın Tekel tarafından ülke sathında dağıtılması, Beykoz'da kurulan cam fabrikasında üretilen ampulün kalıbı kullanılarak, çay için üretilen ince belli bardakların kahvehanelerde yaygın olarak kullanılması, çay kültürünün ülke sathında aynı tüketim biçimiyle yayılmasını sağlamıştır.

1971'de çıkan Çay Kurumu Kanunu'yla 1973'te Çaykur'un kurulması, çay tarımı ve sanayisinin aynı kurumda birleşmesini sağlaması sebebiyle, önemli başarıların ortaya çıkmasına kapı aralamıştır. Illk yıllarda çayın dağıtımı Tekel tarafından yapılırken, daha sonra Çaykur'un kendi bayilik sistemini ve dağıtım kanalını kurması mümkün olmuştur.

1984'ten itibaren 3092 sayılı Kanun'la özel sektöre çay işleme, üretim ve satış izni verilmesiyle yeni bir döneme girilmiştir. Bu dönemde çayla ilgi yasal mevzuat bir hayli azaltılmış, kurallar hafifletilmiş ve serbestleşme (deregülasyon) yaşanmıştır.

Bu dönemde, bir büyük girişimcilik olayı olarak çok sayıda çay işleme atölye ve fabrikası kurulmuş, ancak paketleme ve pazarlama kısmında aynı başarı yakalanamayınca birçok tesis kapanmıştır. 2004'te tespit edilen 144 kapanan tesis sayısı (Saklı, 2004), yaşanan sorunların büyüklüğünü göstermek için yeterlidir.

Özel kesime çay sektöründe faaliyet izni verilmesiyle birlikte, kamu ve özel olarak sektörün bütününü kapsayan politikaların uygulanamaz hale gelmesi, buna karşılık serbestleştirme ile çay sektörüyle ilgili kuralların bir hayli azaltılmış olması, sektördeki sorunların çözümünü zorlaştırmıştır.

Yasal mevzuat eksikliği ve kural koyacak otorite bulunmaması gibi sebeplerle, zayıf özel sektör çay atölyeleri yıllarca üreticinin yaş çay bedellerini zamanında ödemedikleri halde, üreticiyi koruyacak hiçbir tedbir alınamamıştır. Yine aynı dönemde ortaya çıkan paket taklitçiliği ve kalite düşüklüğü gibi sorunlarla başa çıkılması kolay olmamıştır. Bu sorunlar ancak uzun yıllar içinde, zayıfların ve taklitçilerin piyasa tarafından elenmesiyle çözülebilmiştir.

Halen Çaykur'un rakibi olan özel sektörle ilgili kural koyma hak ve yetkisine sahip olmaması, yasama organı dışında kural koyacak başka bir yetkili kurumun da bulunmaması sebebiyle serbestleşme (deregulasyon) 1984'teki biçimiyle devam etmektedir.

Mevcut durumda Türk çay sektörünün mevzuatla bağlantılı temel sorunları şu şekilde ifade edilebilir:

1. Çay konusunun bir KiT olan Çaykur'a verilmiş olması ve sektörde yaklaşık $\% 50$ paya sahip özel kesim üzerinde (ticari rakipleri olduğu için) Çaykur'un kural koyma ve uygulama yapma yetkisinin olmaması sebebiyle, sektörün bütününü kapsayacak politikaların geliştirilmesi mümkün olamamaktadır.

2. Ülke çapında dağıtım kanalına sahip olmayan ve pazarlama sorunu yaşayan küçük işletmelerin bu sorununu çözecek bir mekanizma bulunmaması sebebiyle, sektörde firma kapanmaları ve iflaslar çokça yaşanagelmektedir.

3. Çaykur ve özel sektörün uyması gereken; sektörel bazda çay imalat standartları belirlenmediğinden, az sayıda sorunlu firmada da olsa standart dışı üretim sorunları ortaya çıkabilmektedir.

4. Türk çayı \%145 gümrük vergisi ile korunmakta olduğundan, yabancı çayların paketsiz ve açık olarak kaçak yollarla ülkeye girmesi kaçakçılar için kârlı olabilmekte ve kaçakçılık önlenememektedir. 
5. Sosyal güvenlikten yoksun olduğundan, yöre insanının ilgi göstermediği ve yabancı (Gürcü) işçilerle yürütülen yaş çay toplama işinin, 150-200 TL arası yüksek günlük ücretlerle yapılması sebebiyle önemli bir parasal kaynağın yurt dışına çıkması.

6. Rize'nin Hemşin ilçesi ve Çayeli'nin Kaptanpaşa yöresinde başlatılan organik çay üretiminin, çay üretim havzasının tamamına yayılması konusunun çözümlenememesi.

Yukarıdaki değerlendirmeler ve tespit edilen sorunlar ışı̆̆ında, çay sektörünün daha iyi bir işleyişe kavuşması için bir kısım öneriler getirmek yararlı olabilir:

1. Sektörün tamamını kapsayacak politikaların belirlenmesini ve uygulama alanına geçirilmesini sağlayacak bir üst kuruluş olarak Çay Kurulu'nun kurulması yararlı olacaktır. Türk çaycıığının varlığını sürdürmesi ve sorunlarının çözüme kavuşturulması gibi önemli konular, çay kurulu sayesinde hayata geçirilebilecektir.

2. 2009 yılında başlayan bir süreçte hazırlanan ama yasalaşmayan çay kanunu çalışmasında, Çay Kurulu ile birlikte çay borsası da yer almaktaydı. Çay borsasının sektördeki bütün aktörlerin zorunlu katılımıyla hayata geçirilmesi; sektörün kalitede yarışa sokulması, ülke çapında dağıım kanalı olmayan küçük işletmelerin ürettikleri çayı borsaya satmak suretiyle varlığını sürdürmesi ve sektörde arz ve talep koşullarının etkin piyasa mekanizmasıyla yönlendirilmesi gibi yararlı sonuçlar doğurabilecektir.

3. Çay sektöründe standart dışı üretim yapan az sayıdaki firmayı kurallarla bağlayacak ve tüketici haklarını koruyacak bir yasal zemin hazırlanması; imalat standartlarının belirlenmesi ve tüm sektörde uygulanması çay kurulu ve kapsamlı bir çay yasası ile mümkün olabilecektir.

4. Kaçak çay sorunu, ülkenin Güneydoğu Bölgesi'nde bir tüketim alışkanlığı durumundan, ülke sathına yayılı sağlıksız bir paketsiz "açık çay" satışı durumuna evrilmiştir. Bu konuda sıkı kurallar belirlenmesi ve uygulanması yararlı olacaktır.

5. Sosyal güvenlikten yoksun bir yaş çay toplama iş̧̧iliğinin var olması sebebiyle yöre insanının ilgi göstermediği ve yabancı (Gürcü) işçilerle yürütülen yaş çay toplama işinin şirketler aracılığıyla yapılması önemli bir çözüm sağlayacaktır. Sektörde yaş çay bedelinin \%60-70'ine varan yüksek yaş çay toplama işçiliğinin mevcut olması, önemli bir kaynağın yabancı işçiler aracılığıyla yurt dışına çıkmasına yol açmaktadır. Çalışanlara sosyal güvenlik sunacak şirketlerin çay bahçesi sahipleri ile yapacağı sözleşmelere dayalı olarak oluşturulacak yeni bir yaş çay toplama sistemi, hem tarım işçiliğine sosyal güvenlik sağlama hem de kaynakların yurt içinde kalması gibi önemli yararları beraberinde getirecektir.

6. Tarım ilacı kullanılmayan sektörde organik gübre kullanımının altyapısı oluşturularak tümüyle ekolojik tarıma geçilmesi ve Türk çayının tamamen organik çay olarak üretilmesi zaman zaman ifade edilmektedir. Bunun başarılması için gerekli kurumsal ve yasal altyapının oluşturulması; sorumlu kuruluş olarak çay kurulunun kurulması ve organik tarımı destekleyecek bir çay kanunu ile mümkün olabilecektir.

Gerek çay kurulunun, gerekse çay borsasının kuruluş ve işleyişi yasal bir altyapıya ve ayrıntılı düzenlemelere ihtiyaç duyacağından, çay sektöründeki serbestleşme (deregulation) uygulamasının sona ermesi zorunlu olacaktır. 


\section{Kaynaklar}

1497 sayılı Kanun Teklifi, Trabzon Milletvekili Ahmet Şener ve 9 arkadaşının, Türkiye Çay İşletmeleri Kurumu kanunu teklifi ve 32 numaralı Geçici Komisyon raporu, TBMM Tutanakları; Millet Meclisi 3.Dönem, 1.Toplantı, S.Sayısı 203.

1938 Ziraat Kongresi, Meyvecilik-Bağcılık-Sebzecilik-Çay Genel Raporu ve Beş Senelik Program, T.C. Ziraat Vekâleti Neşriyatı, Ankara, 1938.

06.02.1924 Tarih ve 407 Sayılı Rize Vilâyetiyle Borçka Kazasında Fındık, Portakal, Limon, Mandalina ve Çay Yetiştirilmesi Hakkında Kanun.

02.04.1940 tarih ve 3788 Sayılı Çay Kanunu, Resmi Gazete, Sayfa: 13582, 02 Nisan 1940.

07.06.1949 tarih ve 5433 Sayılı Devlet Üretme Çiftlikleri Genel Müdürlüğü Görev ve Kuruluş Kanunu, RG; 13.06.1949/7231

24.11.1994 tarih ve 4046 sayılı Özelleştirme Uygulamaları Hakkında Kanun, RG: Tarih: 27.11.1994 Sayı: 22124.

4.12.1984 tarih ve 3092 sayılı Çay Kanunu, RG: Tarih: 19.12.1984 Sayı: 18610.

Aktan, R. (1946), Rize'de Çay, Çankaya Matbaası, Ankara.

Connely, A. (2011), “Boston Tea Party”, http://www.lbma.org.uk/assets/Alchemist/Alchemist_91/Alch91Connelly.pdf; (07.01.2019).

Çay Bahçesi Kuracak Olanlara Ruhsatname Verilmesinde Uygulanacak Esaslara Dair Yönetmelik, Resmi Gazete Tarihi: 30.07.2013 Resmi Gazete Sayısı: 28723

Çay İşletmeleri Genel Müdürlüğü Ana Statüsü, RG: 20.12.1996 Sayı: 22853.

Çaykur, Faaliyet Raporu, (2017), 2017 Yılı Çaykur Faaliyet Raporu; http://www.caykur.gov.tr/CMS/Design/Sources/Dosya/Yayinlar/241.pdf; (20.01.2019)

Çaykur İstatistik Bülteni, (2017), İstatistik Bülten 2017; http://www.caykur.gov.tr/CMS/Design/Sources/Dosya/Yayinlar/281.pdf; (20.01.2019)

Derin, Z. ( ? ), Çay uzmanı Mr. Moore'un sorularına verdiği cevaplar, Zihni Derin'in torunları tarafından Recep Koyuncu'ya verilen evrak-i metrukesinden çıkan belge.

Erten, A.R. (1925), Şimali Şarki Anadolu ve Kafkasya'da Tetkikat-ı Ziraiye, İktisat Vekâleti Neşriyatı, İstanbul, (1341).

Hatipoğlu, Ş. R. (1939), Türkiye'de Çay iktisadiyatı, T.C. Ziraat Vekâleti Yayını, Ankara.

Kejanlı, T., Akın, C.T., Yılmaz, A., (2007), “Türkiye'de Koruma Yasalarının Tarihsel Gelişimi Üzerine Bir İnceleme”, Elektronik Sosyal Bilimler Dergisi, Kış 2007 C.6 S.19 ss.179-196.

Kemaloğlu, M., (2015), "Türkiye'de Afet Yönetiminin Tarihi ve Yasal Gelişimi”, Akademik Bakış Dergisi, S.52, Kasım Aralık 2015, Celalabat.

Kenya Tea Act, (1961), Kenya Tea Act ; http://extwprlegs1.fao.org/docs/texts/ken63663.doc; (07.01.2019).

Kumbasar, Sami, (2014), Trabzon Bilinenin Aksine Destek Oldu, Haberci53, 02.08.2014; http://www.haberci53.com/sami-kumbasar-trabzon-bilinenin-aksine-destek-oldu-makale,879.html (09.08.2018).

Özçelik, A.E., Nişancı, R., Demir, O., Yıldırım, V., Yıldırım, R.E., (2013), Çay Tarımı Arazilerinde Konumsal Veri Altyapısı Gereksinimi, Türkiye Ulusal Fotogrametri ve Uzaktan Algılama Birliği VII. Teknik Sempozyumu (TUFUAB'2013), 2325 Mayıs 2013, KTÜ, Trabzon.

Öztürk, S. (2016), İsmet Paşa'nın Kürt Raporu, Doğan Kitap, 7.b.

Rize Ticaret Borsası Kayıtları, 30.07.2018.

Rize Ticaret Borsası, (2019), Çay Kanunu Taslağı, https://www.rtb.org.tr/tr/cay-kanun-taslagi; (12.01.2019)

Saklı, A.R. (2004), Çay Sektöründe Sorunlar ve Çözüme Yönelik Model Arayışları, TODAiE, Kamu Yönetimi YüksekZiHNiOĞLUI Lisans Programı (Yayınlanmamış Yüksek Lisans Tezi), Ankara 2004.

Saklı, A.R., (2008), Türk Çayının Dünü ve Bugünü, Kaknüs Yayınları, İstanbul.

Saklı, A.R. (2011), "A Critical Review of Recent Sectoral Structure Proposal for Turkish Tea Sector", Humanity \& Social Sciences Journal Vol. 6, No. 1: 01-07, 2011.

Sarma, G, (2013), "A Historical Background of Tea in Assam", the Echo An Online Journal of Humanities \& Social Science, Published by: Dept. of Bengali Karimganj College, Karimganj, Assam, India; http://shodhganga.inflibnet.ac.in/bitstream/10603/137485/8/08_chapter_02.pdf; (08.01.2019)

Sri Lanka Tea Board Law, (1975), Sri Lanka Tea Board Law No. 14; http://www.commonlii.org/lk/legis/num_act/sltbl14o1975214/longtitle.html; (07.01.2019). 


\section{Eskişehir Osmangazi Üniversitesi IïB Dergisi}

T.C. Başvekâlet, Kararlar Dairesi Müdürlüğü, 10 Mayıs 1940 tarih ve 2/13450 sayılı Kararname. BCA.030.18.01.02/9144 10.

T.C. Başvekâlet, Kararlar Dairesi Müdürlüğü, 25 Ağustos 1942 tarih ve 2/18662 sayılı Kararname. BCA.030.18.01.02/99.78.14

T.C. Başvekâlet, Kararlar Müdürlüğü, 01.11.1946 tarih ve 3/4889 sayılı Kararname. BCA.030.18.01.02/112.69.17.

T.C. Başvekâlet, Kararlar Müdürlüğü, 20.05.1949 tarih ve 3/9357 sayılı Kararname. BCA.030.18.01.02/119.42.18.

T.C. Başvekâlet, Muamelat Müdürlüğü, 01.04.1933 tarih ve 14108 sayılı Kararname. BCA.030.18.01.02/35.22.11.

TBMM Zabıt Ceridesi, 1.cilt, 29.İctima, 20.03.1940.

TBMM Zabıt Ceridesi, 1.cilt, 65.İctima, 09.05.1927.

TBMM Zabıt Ceridesi, 2.cilt, 91.İctima, 28.01.1340 (1924)

TBMM Zabıt Ceridesi, 2.cilt, 95.İctima, 04.02.1340 (1924).

TBMM Zabıt Ceridesi, Çay Kanunu Layihası ve Ziraat, Maliye, Adliye, Bütçe encümenleri mazbataları (1/218) S Sayısı 70. 9.cilt, Devre: 6 İctima:1, 18.03.1940.

Tea Control Act, (1957), Tea Control Act No. 51; http://srilankalaw.Ik/Volume-VIII/tea-control-act.html; (07.01.2019); Orijinal metin için; http://extwprlegs1.fao.org/docs/pdf/srl21786.pdf; (07.01.2019).

Tea Convention, (2017), The Legendary Colombo Tea Auction, Colombo International Tea Convention 2017; https://www.ceylonteaevents.com/legendary-colombo-tea; (08.01.2019)

Teasrilanka, (2017), Ceylon Tea History, Tea Exporters Association Sri Lanka http://teasrilanka.org/history; (08.01.2019).

The Tea Act, (1953) The Tea Act; https://indiacode.nic.in/bitstream/123456789/2175/3/A1953-29.pdf\#search=tea; (07.01.2019).

Ulusal Çay Konseyinin Kuruluşu ile Çalışma Usul ve Esasları Hakkında Yönetmelik, Resmi Gazete Tarihi: 08.05.2008 Resmi Gazete Sayısı: 26870

Zihnioğlu, A. (1998), Bir Yeşilin Peşinde, TÜBiTAK Yayını, Ankara. 